\title{
Will EMU Increase Eurosclerosis? ${ }^{\infty}$
}

\author{
Gilles Saint-Paul \\ Universitat Pompeu Fabra and cepr
}

Samuel Bentolila

cemf $\mathrm{i}$ and cepr

\begin{abstract}
A bstract
In this paper we study the relationship between labor market institutions and monetary policy. We use a simple macroeconomic framework to show how optimal monetary policy rules depend on labor institutions (labor adjustment costs, and nominal and real wage rigitidy) and social preferences regarding infation, employment, and real wages. We also calibrate our model to compute how the change in social welfare brought about by giving up monetary policy as a result of joining the E conomic and M onetary U nion (EMU) depends on institutions and preferences. We then use the calibrated model to analyze how EMU axects the incentives for labor market reform, both for reforms that increase the economy's adjustment potential and for those that axect the long-run unemployment rate.
\end{abstract}

${ }^{x}$ T his study has been prepared within the UNU/W IDER project on "EM U: I mpact on Europe and the World", which is directed by Charles Wyplosz and ..nancially supported by the Yrjö J ahnsson Foundation and by the Ministry for Foreign A aairs of Finland. We are grateful to Charles Wyplosz, and to our discussant, R oberto Perotti, for useful comments. We also wish to thank M anuel A rellano, J osé M. Campa, J osé D. López-Salido, Enrique Sentana, J avier Vallés, and J osé Viñals, as well as participants at seminars at the B anco de España, CEM FI, and the W IDER November conference for their comments. 


\section{Introduction}

Over the last ten years, Europe has been engaged in a major policy project: monetary union. At the same time, it has continued facing a major policy problem: unemployment. An ironical observer might therefore ask why so much political capital has been spent on an arrangement that is so remote from the main problem at hand. The answer belongs to politicians, but it is the economist's task to study how monetary union might change the way in which labor market policy is conceived. This question has two sides. First, we may ask what is the best policy to reduce European unemployment, and whether it is changed by Economic and M onetary Union (EMU). Second, we may take a more positive, political economy perspective and ask how the decisions that will actually be taken in the ..eld of labor market policy will be dixerent from the ones that would have been pursued absent EMU.

At face value, a well-trained economist would argue that EMU and labor market policy are largely unrelated. The standard view holds that monetary policy does not axect real variables in the long run. ${ }^{1}$ M onetary union will axect the member economies' responses to asymmetric shocks, and, to the extent that the credibility of the European Central Bank $(E C B)$ is dixerent from that of the original national central banks, their common long-run inłation rate. But European unemployment, which has been high for so long, is usually attributed to long-run real rigidities in wage setting, that prevent real labor costs from adjusting downwards in order to eliminate unemployment. That is, Europe's problem is that the natural rate of unemployment is too high, whereas the monetary stance only axects short-run deviations from that natural rate. The ..rstorder answer is therefore that monetary union should not axect labor market policy.

This argument, however, places too much emphasis on the long run. For private agents that discount the future, the transition to a new long-run equilibrium is at least as important as that new equilibrium. This is particularly so when one takes a political economy perspective, as governments are short-lived and could not care less about what the labor market will look like thirty years from now. The transition path to a new equilibrium following a change in labor market policy will heavily depend on the macroeconomic stance; monetary policy may play an important role in making the transition better, or more acceptable to voters. An important exect of EMU is that it will remove that instrument from national governments, preventing them from using it as an auxiliary policy instrument to deliver the best possible transition path to a new

\footnotetext{
${ }^{1}$ There exists however a line of thought that emphasizes hysteresis phenomena (Blanchard and Summers, 1986, Gottfries and Horn, 1986), according to which a temporary aggregate demand shock has permanent exects on unemployment, that is, it changes the natural rate of unemployment forever. However, the mechanisms that have been proposed for such hysteresis have been dismissed as too weak to generate permanent exects of temporary shocks (Layard, Nickell and J ackman, 1991). Rather, they increase the time it takes for actual unemployment to return to the natural rate following an aggregate demand shock.
} 
natural rate of unemployment.

National monetary policies also help to insulate one country from a shock occurring in other countries. In this respect, while convergence has been achieved in ..scal and monetary indicators, and while steps have been taken to impose convergence of future ..scal policies, labor market policies have not been harmonized and will remain largely idiosyncratic. ${ }^{2}$ This rełects in great part divergence of views about the causes of unemployment and the appropriate remedies (compare, for example, the reforms undertaken in the UK and those undertaken in France), which implies that labor market policy will be a source of asymmetric shocks within EMU. These shocks will spillover from the country where they occur to other countries, and will generate conłicts between countries over the appropriate monetary response from the ECB. Indeed, such a shock, and not a small one, has happened just one year after EMU took ox, namely the introduction of the 35-hour workweek in France in J anuary 2000.

In this paper we analyze the relationship between labor market reform and monetary policy in connection with EMU. We start by providing a short survey which allows us to place our analysis in relation to the (scant) existing literature on EMU and labor market policy (Section 2). We then introduce a simple macroeconomic framework allowing us to characterize optimal monetary policy when performed at the national level (Section 3). We then examine how such policy depends on the type of labor institutions and social preferences de..ned over various objectives -employment, real wages, and infation- prevailing in the economy (Section 4). Characterizing EMU as the inability to carry out country-speci..c monetary policy and calibrating both labor institutions and policy preferences allows us to ..nd how each type of institution modi..es the welfare cost entailed by joining EMU. Interestingly, no general proposition can be established saying that rigidities are always harmful under EMU. Whether a given institution is more costly or more bene..cial under EMU than under a sovereign monetary policy depends on social preferences. On the basis of these results, we then assess how EMU modi..es the incentives for labor market reform (Section 5). We distinguish between reforms which only improve the economy's dynamic adjustment potential with no long-run exects, from those which also lower the steady-state unemployment rate. For the latter we ..nd that while EMU clearly makes sizable reforms harder, it may make small reforms easier. We end with a set of conclusions (Section 6).

It is worth advancing our main policy conclusions:

2 EMU creates incentives to alter the economy's structure in order to improve its response to shocks. However, depending on which institution one is talking about, and on the country's preferences, this may well lead to more rigid labor markets. For example, employment protection destabilizes prices but it stabilizes employment. EMU increases the incentives to get rid of employment protection

\footnotetext{
${ }^{2}$ See Bean et al. (1998) for evidence and discussion.
} 
except if society cares a lot about stabilizing employment, in which case it would actually create incentives to tighten employment protection legislation-this does not occur in our simulations but it could for governments that put a high weight on employment.

2 EMU reduces the incentives for a large scale reform of the labor market that would substantially lower unemployment, because monetary policy is very useful in order to get the best possible transition path to the new equilibrium. Consequently, we expect more timid reforms to prevail under EMU.

2 Optimal monetary policy at the time of a labor reform involves a sharp depreciation in the short run, which speeds the transition toward the higher employment level. This is consistent with the two-handed approach view, according to which macroeconomic stimulus should accompany structural reforms.

2 In this respect, an important limitation to structural reforms under EMU is their potential deł ationary impact. If deł ation is to be avoided, the maximum size of a reform will be smaller the lower the common trend of infation in the monetary union.

2 Finally, to overcome the disincentive exects of EMU on labor market reform, there is a case for coordination of labor market reforms across E uropean countries. This will allow the ECB to engineer a monetary expansion in the Union at the same time as all member countries engage in structural reforms, thus implementing the two-handed approach at the union-wide level.

\section{Literature on EMU and labor market reform}

Until recently, most macroeconomic work on EMU has revolved around its desirability and viability. The traditional discussion has focused on two issues. First, whether EMU member countries did or did not satisfy the classic conditions established by Mundell (1961) for an optimum currency area -e.g. labor mobility, wage and price ‡exibility, and the presence of ..scal transfers from a central authority-, whose non-ful...lment could create problems in the event of asymmetric shocks. Second, the determinants of the likelihood that those shocks will happen. ${ }^{3}$ Except for the four European Union (EU) countries currently outside EMU, that discussion seems dated. As of 2000, EMU is up and running, and the most likely scenario is that it will be viable. It is time to move on to the issue of how EMU will axect macroeconomic developments in the Euro countries.

\footnotetext{
${ }^{3}$ See Bean (1992) or W yplosz (1997).
} 
Since EMU entails a change in a monetary arrangement, it is natural to expect it to axect mostly nominal variables, such as the level of inłation or the degree of nominal wage inertia. In ation is likely to be low, in view of the mandate for price stability enshrined in the statute of the ECB. The current EMU-wide infation target of the ECB is a band going from zero to $2 \%$. As to nominal wage inertia, there are theoretical predictions either way, as Calmfors (1998) has noted. It will decrease if the lack of response of the ECB to country-speci...c shocks leads to larger demand shocks on average, and this induces wage setters to shorten wage contract periods. Inertia may however increase due to resistance to money-wage cuts in a low inłation environment, for various reasons (for instance, coordination failures, hold-out clauses, or social norms about fairness). E mpirically, both Calmfors (1998) and Burda (1999) present informal evidence suggesting a trend towards increased nominal wage ‡exibility.

But EMU may have real, rather than just nominal, exects as well. ${ }^{4}$ Some exects would be direct. For example, EMU may increase the degree of competition in European labor markets, through increased economic integration. The single currency has reduced transaction costs and suppressed exchange rate volatility, both of which should increase trade łows among EMU member countries. It also increases transparency about price dixerentials across countries, which should enhance competition throughout the Euro zone. Both channels should increase the wage elasticity of labor demand and as a result weaken the bargaining power of labor unions, which should itself yield higher real wage łexibility. ${ }^{5}$ One may be skeptical about direct exects, because they depend on EMU leading to signi..cantly higher trade ‡ows than those already spurred by the E uropean Single Market which started in 1993. It can be argued that the trade exects of EMU might not be very large, in view of the small empirically estimated exects of exchange rate volatility on trade. ${ }^{6}$

Also, Danthine and Hunt (1994) have pointed out that a single product market in the EU implies a de facto reduction of the degree of centralization of wage bargains. This may change the trade-oxs faced by wage setters in countries with very centralized bargaining, like Scandinavian ones. This ‡attening out of the Calmfors-Driф II (1988) hump shape -as Burda (1999) puts it- means that it may not be so advantageous to have a nation-wide bargain any more, and this could shake collective bargaining in EU countries towards more decentralized structures. ${ }^{7}$

Recent work has focused on indirect, rather than direct, links, through which EMU

\footnotetext{
${ }^{4} \mathrm{~A}$ discussion of the range of potential exects of EMU on European unemployment appears in Viñals and J imeno (1998).

${ }^{5}$ See Andersen and Sorensen (1993) for a theoretical model about this channel, and Andersen et al. (2000) for a discussion of other channels.

${ }^{6}$ See Commission of the European Communities (1990). Nevertheless, Rose (2000) claims that a currency union has further, much stronger trade exects.

${ }^{7}$ Cukierman and Lippi (1999) argue that E uropean labor unions will become more agressive as a result of EMU, because the exects of their actions will be diluted in the EMU-wide labor market.
} 
might lead governments to modify labor market regulations. Let us brieły spell out the steps of the argument, since they are partly relevant to our story too. Persistently high unemployment rates have characterized most continental E uropean countries since the 1970s, with the average unemployment rate in the 11 Euro countries hovering around $10 \%$ in the last 15 years of the century. The currently leading hypothesis is that high structural unemployment rates can be explained, to a large extent, by the type of labor market institutions prevailing in those countries, such as ..ring costs, unemployment bene..ts, collective bargaining regulations, etc. (see L ayard et al., 1991, and Blanchard and Wolfers, 1998).

In spite of both this academic view and the tremendous costs imposed by high unemployment, most EU governments have been unable or unwilling to reform their labor market institutions, or they have done so in a very slow and partial way. ${ }^{8}$ The leading explanation for the lack of reform is that existing institutions represent a political equilibrium. The recent political economy literature provides various mechanisms through which deviating from that equilibrium entails signi..cant political costs which serve to entrench it (see, e.g., Saint-Paul, 1996). An intriguing question is therefore whether EMU, while bearing no direct relation to it, could help solve the European unemployment problem, by providing an exogenous shock that will rock the status quo in a way that favors reform.

Indeed, the conventional wisdom prevailing today is that EMU will eventually remove some barriers to labor reform. Governments of EMU countries have lost monetary policy as a tool to oxset economic shocks and they may also see their hands tied regarding ..scal policy by the Stability and Growth Pact. Bean (1998) argues that once the easy option to devalue their currency has been lost, they will have no alternative but to try to make their economy more fexible through labor market reform. This is a version of the TINA (There-Is-N o-A Iternative) argument which became famous in the UK during the Thatcher years.

A few authors, however, provide arguments against this view. Both Sibert and Sutherland (1997) and Calmfors (1998) do so by extending Barro and Gordon's (1983) well known monetary policy model, where governments dislike deviations of inłation and unemployment from some target values, but cannot credibly commit on a policy rule. Labor market reform is costly for the government, presumably for political reasons. But it is also desirable: it directly reduces equilibrium unemployment and, because it also reduces the infation bias (the reward from being able to surprise price and wage setters), it ends up indirectly reducing in ation as well. In this sense, labor reform yields a double dividend. Now, the ECB is not guided by the infation and unemployment rates of a particular country, but by (some) EMU averages. Then the

\footnotetext{
${ }^{8}$ See, e.g., Bertola and Ichino (1995) or Saint-Paul (1996). The UK and The Netherlands can be considered as exceptions to this rule. See Nickell and van Ours (2000) for a description of the labor markets in these two countries.
} 
marginal bene.t from labor reform is smaller inside than outside EMU, because unemployment in an individual member country has a smaller impact on the monetary policy of the ECB than it had on the national central bank's policy, and thereby a lower impact on EMU-wide equilibrium unemployment and infation rates as well. The prediction is, therefore, that there will be less reform as a result of EMU.

There exist other arguments for why labor reform may be either easier or harder inside than outside EMU. Bean (1998) points out that it might be harder if the costs from reform come upfront while the bene.ts take longer to materialize. ${ }^{9}$ In such case, outside EMU monetary policy can be used to ease short-run costs, so that reform is viable in the ..rst place, but not inside EMU. On the other hand, in the absence of an in $\neq$ ation bias, there is a stronger incentive for labor reform inside E MU if policymakers wish to avoid very bad outcomes regarding unemployment (i.e., they have a precautionary motive), since the ECB does not stabilize country-speci..c shocks ( $C$ almfors et al., 1997).

Finally, Saint-Paul and Wasmer (1999) study national labor market policies as the outcome of a strategic game between national governments and the European Central Bank, so that the multi-country aspect of EMU plays a key role.

Our model dixers from the ones discussed so far in several respects. First, we explicitly distinguish among dixerent labor market rigidities. More speci..cally, we make a distinction between four kind of rigidities: those which increase the ability of incumbent employees to get rents, those which reduce the response of real wages to labor market disequilibrium, those which increase nominal inertia in wage setting, and those which increase the cost of adjusting employment. We show that they have dixerent impacts on the cost of belonging to EMU, or, conversely, that EMU membership axects the incentives for labor market reform in dixerent directions depending on which type of rigidity we are considering. Second, we incorporate political economy considerations in our analysis by allowing social preferences to rełect incumbent employees' (or unions') preferences for real wage stability. Third, we relax the assumption that only long-run infation and unemployment outcomes matter and take into account the role of monetary policy in the transition between steady states. In this way, our approach rełects the two arguments put forth by Bean (1998), as just discussed. Fourth, we calibrate a set of parameters which proxy for the dixerent labor market institutions, so as to gauge the likely importance of contending channels. ${ }^{10}$ Finally, we de-emphasize the role of monetary policy credibility by assuming that even absent EMU, the government can precommit on a monetary policy rule. This assumption refects our belief that absent EMU, governments would have used other devices to achieve credibility, such as central bank independence, which already existed in many countries before they joined EMU.

\footnotetext{
${ }^{9} \mathrm{~T}$ his argument is inspired in the well-known two-handed approach to European unemployment defended by Blanchard et al. (1986).

${ }^{10} \mathrm{Bean}$ (1998) provides a related numerical simulations for the UK on the exects of a generic labor reform which reduces the long-run unemployment rate.
} 


\section{A simple macroeconomic framework}

\subsection{M acroeconomic setup}

B efore dealing with EMU, it is necessary to set up a framework that speaks to the largely untouched issue of the links between monetary policy and labor market policy. Such framework can then be used to analyze what happens if monetary policy is decided by a supra-national central bank rather than a national one.

We shall use a simple Aggregate Demand/A ggregate Supply model consisting of the following equations:

$$
\begin{aligned}
& y_{t}= \pm\left(e_{t} ; p_{t}\right)+{ }_{t} \\
& y_{t}=I_{t}+h+\mu_{t} \\
& p_{t}=w_{t} \text { i } \mu_{t} i h+,\left(l_{t} ; I_{t_{i} 1}\right)+{ }^{-},\left(l_{t} ;\left.E_{t}\right|_{t+1}\right) \\
& w_{t}=(1 ; ®)\left(q+\left(1 ;{ }^{\prime}\right) p_{t}+{ }^{\prime} e_{t}+{ }^{0} I_{t}\right)+\mathbb{B}\left(w_{t_{i} 1}+p_{t_{i} 1} i \quad p_{t_{i} 2}\right)
\end{aligned}
$$

where $y$ denotes output, e the nominal exchange rate (with an increase in e meaning a depreciation), $p$ the price level, $w$ the nominal wage, $h$ a productivity index which may also rełect hours of work per employee, and I employment, all of them in logs, while $\mathrm{E}$ denotes the expectations operator.

Equation (1) is the IS curve, which is reduced to its simplest determinants. The parameter \pm jointly captures the elasticity of imports and exports to the real exchange rate and the degree of openness of the economy. " $t$ is an aggregate demand shock with zero mean and variance $3 / 4$. We take the nominal exchange rate as our policy variable, which allows us to ignore the LM curve and makes it easier to extend the model to a monetary union case. We have not introduced interest rates either. ${ }^{11}$ In fact, the econometric evidence suggests that interest rates do not play a major role in the IS curve. ${ }^{12}$

Equation (2) is the production function, which says that output is equal to employment times hours times productivity. Note that we have ignored the dynamics of capital accumulation.

Equation (3) sets the price equal to the marginal cost of labor. ${ }^{13}$ The term,,$\left(I_{t} i\right.$ $\left.I_{t_{i}{ }_{1}}\right)$ represents current marginal labor adjustment costs: the more employment grows

\footnotetext{
${ }^{11} \mathrm{At}$ the very least, introducing them would require the use of the interest parity condition: $i_{t}=$ $i^{x}+E_{t} e_{+1} i \quad e_{t}$ : This would complicate the dynamics unless the path of future expected exchange rates is $¥$ at, in which case equation (1) simply amounts to a normalization of the foreign nominal interest rate to zero. Note also that there is little evidence in favor of uncovered interest parity (see Obstfeld and Rogox, 1997).

${ }^{12}$ It is usually hard to ..nd signi..cant exects of real interest rates in consumption and investment equations, and the sign of the estimated coed cient often crucially depends on the country and the period. See the surveys on consumption, Muellbauer (1993), and investment, Chirinko (1993).

${ }^{13} \mathrm{~T}$ here could be a constant markup on marginal cost, which is implicitly normalized to one.
} 
relative to past employment, the greater the marginal cost of labor and the greater the price. ${ }^{14}$ Hence, ${ }^{-}$, $\left(I_{\mathrm{t}}\right.$ i $\left.\mathrm{E}_{\mathrm{t}} \mathrm{I}_{\mathrm{t}+1}\right)$ represents future discounted marginal labor adjustment costs, with ${ }^{-}$as the discount factor. $\mu$ is a productivity shock with zero mean and variance $3 / 4$.

Finally, equation (4) represents wage setting behavior. Wages are a weighted average of past wages and current wage aspirations. Past wage contracts are assumed to include a cost of living adjustment, hence the lagged inłation term (which leads to an accelerationist Phillips curve). Wage aspirations include a rent or wage markup, q, on the consumption wage and are an increasing function of employment -thus capturing a positive feedback from labor market tightness to wage setting-. The parameter ' captures the weight of imported goods in the consumer price index.

Labor market policies and institutions are captured by several variables:

1. q rełects wage pressure, or insider bargaining power. The higher $q$, the higher the rent that incumbent employees can grab on the job. q can also be interpreted as capturing any outside factor that boosts wages, such as unemployment bene.ts.

2. ${ }^{\circ}$ reł ects real wage łexibility, that is, how much wages respond to outside labor market conditions. The lower ${ }^{\circ}$, the more insiders can insulate wage setting from outside labor market conditions.

3. rełects labor adjustment costs (hiring and ..ring costs), which are in part determined by regulation. Employment protection legislation and hiring regulations, such as the prohibition of temporary work agencies or the establishment of a compulsory priority hiring list, all increase. .

4. ${ }^{\circledR}$ is the degree of nominal wage rigidity. Following Taylor (1980) and Calvo (1983), it may refect the fraction of nominal wage contracts that are not renegotiated in any given period. It may also rełect social norms against nominal wage cuts, as documented in Bewley (1998) and A kerlof, Dickens, and Perry (1996). (B) is to some extent axected by policy regarding contract length, backward indexation, etc. Finally, we can also interpret it as representing the importance of minimum wages, assuming that these are indexed on last period's average nominal wage. Under this interpretation, ${ }^{\circledR}$ would be the fraction of workers being paid the minimum wage.

One diф culty is that these parameters do not correspond exactly to real-world labor market institutions. For example, ...ing costs will increase the adjustment cost , , but at the same time they are likely to increase workers' bargaining power (Lindbeck and Snower, 1988), thus increasing $q$ and possibly reducing ${ }^{\circ}$.

\footnotetext{
${ }^{14}$ T his is again quite standard (see Layard et al., 1991, ch. 9).
} 


\subsection{M onetary policy}

We now turn to the speci..cation of the objective function of the policymaker. The standard practice, following Barro and Gordon (1983), is to assume that the government cares about output and infation. We depart from standard practice by allowing public decisions to be axected by pressure groups representing the interests of incumbent employees. Thus we shall assume that policymakers minimize the following loss function:

$$
V_{t}=E_{t_{i} 1}^{* 1}(1+r)^{i(s i t)} U_{s}
$$

where $r$ is the discount rate and $U_{s}$ the instantaneous utility function, given by:

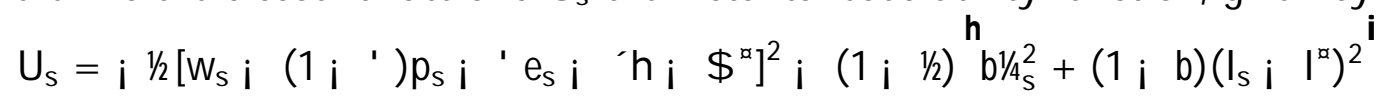

where $1 / 4{ }^{\prime} \quad p_{t} p_{t_{i} 1}$ denotes the infation rate, $\$^{\text {a }}$ the union's desired level for its objective, and $I^{x}$ the government's employment level objective. ${ }^{15}$

The ..rst term in brackets retects the political power of insiders (as opposed to their bargaining power refected in parameters $q$ and ${ }^{\circ}$ ). The utility of insiders depends on their real consumption wage and their leisure, i.e. it is decreasing in hours of work. The second term is the usual social welfare function in terms of infation and output, except that, given supply shocks, it makes more sense to use employment rather than output. ${ }^{16}$ The parameter $b$ captures the weight of infation in this welfare function. The union objective and the welfare function come with weights $1 / 2$ and $1 ; 1 / 7$ with $1 / 2$ therefore measuring the political power of incumbent employees.

\subsection{Long- and short-run equilibria}

This model allows us to describe the exchange rate policy followed by the government under various hypotheses and to see how it depends on labor market institutions. The ..rst step is however to characterize the solution as a function of the monetary policy followed. A ssuming a stationary monetary policy rule, real variables will łuctuate along their long-term averages, which are computed by setting all shocks to zero, current values equal to past values, and expectations equal to realizations for all variables. They are given by:

$$
\mathrm{f}=\frac{\left( \pm \mathrm{i}^{\prime}\right) \mathrm{h}_{\mathrm{i}} \pm \mathrm{q}}{{ }^{\prime}+{ }^{\circ} \pm} ; !=\mathrm{h} ; \mathrm{x}=\frac{\left(1+{ }^{\circ}\right) \mathrm{h}_{\mathrm{i}} \mathrm{q}}{1+{ }^{\circ} \pm} \text {; and } \boldsymbol{y}= \pm \frac{\left(1+{ }^{\circ}\right) \mathrm{h}_{\mathrm{i}} \mathrm{q}}{1+{ }^{\circ} \pm}
$$

\footnotetext{
${ }^{15}$ W hile originally posed in ad-hoc manner, the social welfare function of B arro and Gordon (1983) can be derived as a second-order approximation within a utility-maximizing framework. See Rotemberg and Woodford (1997) and E rceg et al. (1999).

${ }^{16}$ There is no a priori reason why a benevolent policymaker would like to stabilize output in the face of supply shocks. In the ..rst best, full employment outcome output should react one for one with supply shocks, if labor supply is inelastic.
} 
where, hereafter, we de..ne $x_{t}{ }^{\prime} e_{t} i p_{t}$ as the real exchange rate and $!_{t}=w_{t} i p_{t}$ as the real (product) wage. $N$ ote that we can express the solution in terms of $x$ and !. The in $\ddagger$ ation rate is equal to the exogenous trend of nominal depreciation, which we assume is equal to zero (under commitment this is optimal, since there is no long run trade-ox between in $\ddagger$ ation and real variables). Thus: $\mathbf{1} / \mathbf{4}=0$. The price level is indeterminate unless there is a nominal anchor, which is obviously the case under EMU. However with a national monetary policy it is not optimal to have a nominal anchor, since it is infation and not the price level that appears in the objective function in equation (6).

The short-run equilibrium can be solved by using standard rational expectations techniques. We proceed in two steps. First, we assume there is a pre-set monetary policy rule and then solve for the state variables of the model -as deviations from their long-run equilibrium values-, whose expressions are functions of the policy parameters. Second, given this relationship, we derive the parameters of the optimal policy rule. The details are in A ppendix 1 and further discussion is provided in the next section.

\section{Labor institutions and optimal monetary policy}

We aim at ..nding out how optimal monetary policy depends on labor market institutions. The non-linear way in which the parameters enter the solution for both the endogenous variables and the policy rule leads us to calibrate all the parameters, so that they are deemed to be representative of OECD economies, and then solve numerically for the optimal policy rule. We start by justifying the parameter choices made, we then brieły discuss the procedure for ..nding the optimal monetary policy, and we ..nally present the simulation results.

\subsection{Calibration of parameters}

\subsubsection{Labor market institutions and political economy parameters}

We need to choose values for the parameters capturing labor adjustment costs, real wage $\ddagger$ exibility, and nominal inertia $\left(,{ }^{\circ}\right.$, and ${ }^{\circ}$, respectively) that characterize the state of the labor market. For each of the parameters we choose two values, one representing a fexible economy and the other a rigid one. These values are based essentially on the estimates of Layard, Nickell, and Jackman (1991) for 19 OECD countries over the period 1969-85. These authors also provide simple cross-section regressions of the country-speci..c coec cients on several proxies for the a priori relevant institutions with reasonably favorable results.

Out of the 19 countries for which they provide estimated parameters, we compute the averages over the countries showing the upper and lower values so as to de..ne the rigid and ‡exible economies (respectively, lower and upper in the case of ${ }^{\circ}$ ). These 
average values turn out to be quite similar across various empirical studies. ${ }^{17}$ Table 1 shows our calibrated parameters (see A ppendix 2 for details).

O ur parameter space therefore de..nes eight virtual economies, each of them being labeled in Table 2 with an appropriate nickname. Although the parameter ranges are quite similar across empirical studies, the rankings of countries with regard to speci..c parameters are not so similar. Thus, we must exercise some judgement in the choice of nicknames. Bruno and Sachs (1985) established the stylized fact of the US having nominal wage rigidity and real wage łexibility, while both continental Europe and the UK had the opposite. ${ }^{18}$ We take Scandinavian countries to be more like the US in this respect and J apan to enjoy overall łexibility. As to labor adjustment costs, we only label the UK and the US as being łexible.

As to social preferences, we know of no evidence regarding the union political in¥uence parameter $1 / 2$ and, more surprisingly, of little evidence regarding the in $\ddagger$ ation aversion parameter b. A ballpark estimate for b in 22 OECD countries is 0.74 (from L ippi, 1998, see A ppendix 2). We choose two alternative values for each of $1 / 2$ and b. We characterize economies as having either politically weak unions $(1 / 2=0: 1)$ or politically strong unions $(1 / 2=0: 5)$. W ith respect to in $\ddagger$ ation, they can be either in $\neq$ ation averse $(b=0: 9)$ or infation prone $(b=0: 1)$. In order to streamline the discussion below, we also give nicknames to the resulting combinations, as shown in Table 3. We call an inłation-averse government with a low inłuence of labor unions "Conservative" and one with a high inłuence "Christian Democrat", while an inłation-prone government with a low infuence of unions is dubbed "New Labour" and one with a high infuence is called "Socialist". Hereafter we shall refer to these as policymaker types. We will dispose of the inverted commas from now on, but it should be kept in mind that these nicknames are simply useful shorthand.

\subsubsection{Other parameters}

We also need to quantify a few other parameters (see A ppendix 2 for details). Both the real exchange rate elasticity \pm and the price weight of imports ' are set to 0.2 , following estimates and data averages for OECD countries. The rent $q$ axects averages but not the response to shocks, and therefore does not axect optimal monetary policy. Thus we set it to zero for now. It will play a key role, however, when we consider the incentives for labor reform in EMU.

T wo important parameters characterize the degree of noise in the economy, namely the shock variances $3 / 4$ and $3 / 4.4$. For our simulations we adopt Bayoumi and Eichengreen's (1993) estimates of the standard deviation of demand and supply shocks, de-

\footnotetext{
${ }^{17}$ In particular, we check the estimates against those of Alogoskou..s and M anning (1988), Grubb (1986), and Newell and Symons (1985).

${ }^{18} \mathrm{See}$ also the cross-country results for an alternative measure of real wage łexibility in Viñals and J imeno (1998).
} 
rived from a structural vector autoregression (VAR). Their estimates suggest the values $3 / 4=3 / 4=0: 0004$. We must however note that these variances should be sensitive to which assumptions are made in identifying the VAR.

We need also describe the remaining preference parameters appearing in the utility function (6). The desired long-run objectives are set to $\$^{x}=1$ and $\left.\right|^{x}=0: 1$. With a long-run equilibrium (log) employment level of $\dagger^{\prime}=0$ these values imply that there is an unwanted unemployment rate of $10 \%$. The interest rate entering the objective function is set to 0.1 (and accordingly ${ }^{-}$to 0.9 ) . Lastly, although our model would allow us to study the exects of changes in hours of work, we will not discuss this issue further, and so from now on we set hours of work $h$ to zero.

\subsection{Optimal policy rule}

Our space of 5 parameters with 2 alternative values each de. nes 32 alternative virtual economies. ${ }^{19}$ For each of these we compute the optimal monetary policy in steady state. By steady state we mean that at date $t=0$-when the monetary policy rule is chosen to maximize the objective function in equation (5)- the initial values of prices, employment, and wages are equal to their long-run average levels.

In A ppendix 1 it is shown that the optimal monetary policy determines each period's real exchange rate as a function of the three relevant state variables-employment, real wages, and infation-in the preceding period, and the two current shocks- " $t$ and $\mu_{\mathrm{t}}$ : That is,

$$
\widehat{x_{t}}=x_{0} \hat{t}_{t_{1} 1}+x_{1} r_{t_{i} 1}+x_{2}{ }^{12 / t_{i} 1}+x_{3}{ }^{\prime \prime} t+x_{4} \mu_{t} ;
$$

where a hat denotes deviations from steady-state values. ${ }^{20}$

Optimal policy is de. ned in terms of the set of parameters $x_{i}=f x_{0} ; x_{1} ; x_{2} ; x_{3} ; x_{4} g$, each of which may be either positive or negative. It is optimal for monetary policy to react to past deviations of employment, real wages, and inłation from their long-run equilibrium levels, and also to current aggregate demand and supply shocks. Simultaneously stabilizing employment, real wages, and inłation will usually entail conłicts which the $x_{i}$ coed cients resolve as a function of the weights given to these objectives in equation (6).

\footnotetext{
${ }^{19} \mathrm{~L}$ abor market institutions should be endogenous to social preferences, and so some of the combinations considered might not be politically viable. For simplicity, we shall disregard this issue in our analysis.

${ }^{20} \mathrm{Hence}$, even though the policy variable being used is the nominal exchange rate, the rule is expressed in terms of the real one. The corresponding nominal exchange rate is determined implicitly by (7).
} 


\subsection{M onetary policy, labor institutions and policy objectives}

Table 4 presents the results from our simulations for the dixerent combinations of policymaker preferences and labor market con..gurations. Our goal is to describe how the cost of joining EMU depends on an economy's labor market institutions. We de..ne EMU as ..xing the nominal exchange rate irrevocably, i.e.: $x_{i}=0$, for $i=1 ;: . ; ; 5$. In other words, monetary policy cannot respond to the developments in the economy. To the extent to which supply and demand shocks in any particular country are correlated with those in the other EMU member countries, EMU monetary policy will be partially geared towards infation and employment developments in each country. This degree of gearing should be expected to vary over time. While our characterization of EMU is an extreme one, it has the advantage of bringing out the relationship between the costs of EMU and labor market structure in sharp relief. But it should be kept in mind that the costs from EMU that we compute are an upper bound on the ones that would arise if any cross-country correlation in macroeconomic aggregates was considered.

The welfare cost associated with EMU is given by the dixerence between the policymaker's welfare with the optimal policy and that under EMU. If all the structural parameters characterizing the economy remain constant, then in our model this cost is clearly always positive, since the optimal monetary policy improves over any alternative. Thus, to justify EMU from a welfare perspective we would have to assume the existence of some gain from EMU which is not formalized in our model (e.g. a political gain or a reduction in transaction costs). This choice is consistent with the fact that, as indicated in Section 2, the sorts of structural changes to be brought forth by EMU are unclear. We nevertheless analyze at the end of this section how our results change if we allow for one gain from EMU which is plausible to expect, namely a reduction in the variance of demand shocks.

Let us now discuss Table4. The values reported are the costs from EMU, namely the dixerence between the welfare losses for a country with a given set of labor institutions and preferences inside EMU and those outside EMU. In order to properly compare welfare losses across economies with dixerent preferences (i.e. $1 / 2$ and b) we normalize each loss by the present discounted value of the steady state utility corresponding to the speci..c preference pair. ${ }^{21}$

The ..rst result is that, ironically, the countries that lose less from EMU are of the A nglo-Saxon type, i.e. the UK and the US, while the ones that lose most are the Fully Rigid economy and Scandinavia, closely followed by Europe and J apan. This is true across preference structures. This conclusion is of course worth what our nicknames are.

The table allows us to explain these dixerences by tracing them back to the exects of speci..c labor market institutions on the cost of EMU. For each, we present the average

\footnotetext{
${ }^{21}$ Which is given by $[(1+r)=r]\left[1 / 4 \$^{x}\right)^{2}+\left(1 ;{ }^{1} \not k(1 ; b)\left(I^{a}\right)^{2}\right]$.
} 
cost of EMU for the four economies with a rigid institution and for the four with a fexible one, and then the average rigid-łexible dixerence. Let us start with the labor adjustment cost index. . Table 4 shows that having a rigid employment protection legislation, say, instead of a łexible one increases the cost of belonging to EMU for all policymaker types. To see why, we need to examine how these costs axect the variances of the three variables included in the objective function (6)..$^{22}$ As expected, higher labor adjustment costs stabilize employment but destabilize both prices and real wages. With our parameter space, the former exect is much smaller than the latter two, and so employment rigidity always raises the cost of EMU, for any type of policymaker preferences. There are quantitative dixerences, however: not being able to use monetary policy to oxset those higher variances is particularly costly for a Conservative. The reason is that this type of policymaker cares a lot about infation ( $b$ is high) and, even though it does not care much about the real wage variance $(1 / 2$ is low), the destabilization of prices is much larger than that of wages, yielding an overall lower welfare. ${ }^{23}$

This does not mean that any rigidity increases the cost of EMU. Consider for example real wage $\ddagger$ exibility ${ }^{\circ}$. Table 4 indicates that having rigid real wages actually reduces the cost of EMU - with the exception of the Socialist policymaker-, although the dixerence is small relative to the case of labor adjustment costs. The reason is that a lower ${ }^{\circ}$ stabilizes prices, while destabilizing employment and real wages. While we may have expected a lower ${ }^{\circ}$ to lower the variance of real wages as well, the opposite obtains in general equilibrium under EMU through the higher employment variance, despite the fact that a lower ${ }^{\circ}$ reduces the response of wage aspirations to changes in employment (cfr. equation (4)). This makes a higher wage rigidity more costly under EMU the higher is political union power. Given its price stabilization exect, EMU is on the other hand less costly the higher the degree of infation aversion. As a result, only with a combination of a high union weight plus a low infation weight (e.g. the Socialist policymaker case) can rigid real wages make EMU more costly than having ‡exible wages.

Finally, let us consider nominal wage inertia, ${ }^{\circledR}$. Rigidity entails a higher welfare cost under EMU for in ation-prone policymakers, while the opposite is true for in ation averse ones. Why? Because nominal wage rigidity stabilizes prices but destabilizes employment and real wages. Thus nominal wage rigidity has the same variance exects as real wage rigidity but, as would be natural to expect, it raises the variance of real wages (vis-a-vis łexible nominal wages) signi..cantly more than real rigidity does. As a result, within countries with high nominal wage rigidity, EMU is costly not just for those with politically powerful unions (Socialist) but also marginally for those with

\footnotetext{
${ }^{22} \mathrm{~T}$ hese variance exects are reported in Table A2 of A ppendix 3.

${ }^{23}$ Note that the Christian Democrat policymaker is infation averse as well, but the overall weight of infation is much lower because of the higher weight now placed on real wage stability $(1 / 2=0: 5)$, with the net result of a lower loss than for the Conservative one.
} 
weak unions too ( $N$ ew Labour).

So far we have computed the costs associated with EMU for dixerent labor market and preference structures, which amounts to assuming that those structures will remain unaxected by EMU. One of the variables which may however be directly lowered by EMU is the degree of uncertainty. In reality, a fraction of demand shocks arises from speculation in foreign currency markets. Since E MU suppresses all variation in bilateral exchange rates, it is natural to assume it will reduce the variance of demand shocks. We therefore check the robustness of our results by rerunning our simulations for the case in which EMU lowers that variance by one-third. In this particular choice we follow Canzoneri et al. (1996) (see A ppendix 2).

The reduction in the variance has two exects, with respect to the case of an unchanged variance. ${ }^{24} \mathrm{~F}$ irst, with lower variability, the costs from EMU are reduced in all cases. Second, the reduction in the demand shock variance means that the increase in the variance of real wages caused by nominal wage rigidity is lower than before, so that such rigidity now reduces the cost of EMU even in the New Labour case. Overall, however, the qualitative results are unchanged.

To conclude, both the cost of EMU and the impact of speci..c labor market institutions on this cost crucially depend on the policymaker's preferences. Stringent employment protection legislation tends to increase the cost of EMU, especially for a Conservative policymaker. On the other hand, nominal and real wage rigidity may reduce the cost of EMU as long as the combination of low in ation aversion and politically powerful unions -the Socialist case- does not prevail. These results are summarized in Table 5, both for individual policy objectives and for the combinations of them which we have been considering. In the table, a "+" sign (respectively " $-"$ ) indicates that a more rigid institution increases (respectively reduces) the cost from EMU membership when the policymaker's objective is to stabilize the variable in the corresponding column.

When thinking about the impact of a given labor market institution on the cost of EMU, it is useful to think in terms of substitutability between that institution and the use of active monetary policy. If it is substitute, then having more of it reduces the cost of EMU membership. Substitutability depends both on the institution and public preferences. For example, if one wants to stabilize inłation, employment protection is a poor substitute since it increases the volatility of marginal costs. Therefore, it increases the costs of EMU membership for an infation-averse policymaker. By contrast, it is a good substitute for monetary policy if one wants to stabilize employment; in this case more employment protection should reduce the cost of EMU. However, as we have seen, the employment stabilizing exect is quite small so that even with $b=0: 1$ this exect does not show up in our simulations. Furthermore, the stabilizing exect of an institution in general equilibrium may be quite dixerent from its direct exect. At face

\footnotetext{
${ }^{24} \mathrm{~T}$ he results are reported in Table A3 of A ppendix 3.
} 
value, greater real wage rigidity should lower the volatility of real wages, and therefore it should reduce the cost of EMU when unions are strong. However, it turns out that in general equilibrium a lower ${ }^{\circ}$ actually increases real wage volatility, so that the conclusion is reversed.

Interestingly, there is no general proposition telling us that labor market rigidity makes EMU more costly. It all depends on public preferences and the speci..c rigidity we are talking about. However, a casual reading of the experience of E uropean countries in the 1980's and 1990's suggests that, during the convergence process to EMU, social preferences have drifted from output and employment stability to price level stability. A ccording to our results, given the level of employment protection in these countries, we would expect such a shift to increase the cost of EMU. ${ }^{25}$

\section{Labor market reform and EMU}

The preceding section tells us what is the cost, on average, of losing monetary autonomy for an economy that stays with the same labor market institutions. In this section, we consider the issue from a more dynamic perspective, looking at the cost of EMU for an economy which considers a change in its institutions. Formally, we now look for a policy rule that maximizes welfare under initial conditions that are given by the dixerence between the pre-reform and the post-reform steady states. ${ }^{26}$

We would expect that the more costly is EMU under a given institutional arrangement, the greater the exect of EMU on the incentives to reform that institution. For example, we have seen that the burden of EMU is greater the larger the ...ing cost. Thus, we should logically expect the gains from reducing ...ring costs to be higher under EMU than absent EMU. This, in exect, is the so-called TINA argument described in Section 2 for the supposedly bene..cial impact of EMU on labor market reform. But that reasoning ignores another aspect of monetary policy, namely that it can be used to reduce the cost of the transition to the post-reform steady state, and this transitional role is lost if the country belongs to a monetary union. This is the second argument advanced by Bean (1998), as mentioned in Section 2. In fact, this latter aspect turns out to be crucial, because labor market reform represents a large shock relative to the standard deviation of demand and supply shocks, so that the transitional role tends to

\footnotetext{
${ }^{25}$ Alternatively, it might be argued that governments will care less about infation inside EMU because, having lost control of monetary policy, they will not be held accountable for domestic in $\ddagger$ ation. We do not ..nd this argument very persuasive, since in the end what matters is what the public cares about.

${ }^{26} \mathrm{~T}$ his can be seen as a way to tackle the Lucas critique, namely that estimated parameters characterizing the past behavior of any economy should not be invariant to changes in policy variables. Such critique is of course very relevant regarding a clear and important regime change like EMU. Our approach is to use the model to provide an informed guess as to how the parameters characterizing the economy will change once the monetary policy regime changes.
} 
be quantitatively more important than TINA.

We shall therefore distinguish between two types of reforms. The ..rst one changes the economy's potential to adjust to shocks, but has no impact on its average longrun equilibrium. If the economy starts at this equilibrium, labor reform therefore does not induce any transitional dynamics of its own. The impact of EMU on reform incentives can then simply be recovered from the steady state costs of the pre and post-reform institutions as calculated in the preceding section. The second type of reform is associated with a change in the long-run average steady state of the economy. In this case, the larger the exect of reform on, say, employment, the greater the initial post-reform deviation of employment from average steady-state values, and the greater the value of using monetary policy along the transition path. In other words, EMU is more likely to reduce incentives for reform the larger the reform. Thus, large reforms are clearly harder under EMU, but some small reforms may be easier, a point we will return to below.

In order to analyze speci..c reforms we compute the impact of EMU on reform incentives, which is de. ned as follows:

$$
\begin{aligned}
I & =\left(W_{R E} i W_{R E}\right) ;\left(W_{R E} i \quad W_{R E}\right) ; \\
& =(\text { Value of reform under } E M U)-(\text { Value of reform absent EMU })
\end{aligned}
$$

where $R$ (respectively $R$ ) stands for reform (respectively no reform), E (respectively $\vec{E}$ ) for EMU (respectively no EMU), and W is the corresponding value of the policymaker's objective function. We clearly also have:

$$
\begin{aligned}
I & =\left(W_{R E} i W_{R E}\right) i\left(W_{R E} i W_{R E}\right) \\
& =(\text { Cost of EMU absent reform })-(\text { Cost of EMU under reform) }
\end{aligned}
$$

\subsection{Increasing the economy's adjustment potential}

In the case of a change in one of the parameters that axect the economy's response to shocks but not its long-run average levels of output, employment, and wages, the reform generates no transitional dynamics if the actual initial values of these variables are precisely equal to their long-run levels. In this case the policy rule following reform only rełects the response to shocks and it is rigorous to use Table 4 to compute the impact exect I in equation (8). We follow this approach for three types of reforms: a reduction in employment protection, a reduction in nominal wage inertia, and (in a special case where it does not axect long-term averages), an increase in real wage ‡exibility.

A reduction in ..ring costs, , might also lower insider workers' bargaining power, thus having at the same time a negative impact on $q$ and possibly a positive impact on ${ }^{\circ}$. However, let us proceed in steps and consider ..rst the impact of a reduction 
in the employment inertia parameter, alone (we analyze changes in $q$ in the next subsection). ${ }^{27}$ As indicated in Table 5(B), the average impact of EMU on the incentives to reduce ..ring costs from its rigid level of, $=8$ to its łexible one of, $=1$ is positive for any government. The average dixerences in welfare between countries with rigid employment and those with ‡exible employment in Table 4 shows that this incentive is particularly high for the Conservative policymaker. As previously discussed, this happens because a high, stabilizes employment but destabilizes both real wages and prices, especially the latter, which is the pre-eminent objective for this type of policymaker.

As to nominal wage inertia, ${ }^{\circledR}$, again the impact of EMU on reform incentives is given by the welfare exect of the change from the rigid level of $\Theta=0: 8$ to the $\ddagger$ exible one of $B=0: 45$. Table $5(B)$ indicates that both a New Labour and a Socialist policymaker would have an incentive to increase nominal wage fexibility under EMU. A gain, the reason is that nominal wage rigidity stabilizes prices but destabilizes real wages and employment, with the latter objective being the one that those governments would like to stabilize the most. Table 4 indicates that, with our parameter space, this incentive is quite mild, specially in the case of New Labour (for which the incentive actually disappears if EMU brings about a reduction of the variance of demand shocks).

Lastly, we can discuss real wage $\ddagger$ exibility, ${ }^{\circ}$, in one particular case. If q (insider rents) remains equal to zero, as we have been assuming until now, then an increase in ${ }^{\circ}$ does not axect the long-term values of real wages, prices or employment - which remain equal to zero-. In this case a higher ${ }^{\circ}$ means that real wages are more responsive to shocks but the long-run level of employment remains the same. Then the impact of EMU on reform incentives can be computed exactly as for the other two institutions. Table 5(B) shows that only for the Socialist policymaker does E MU provide an incentive to increase ${ }^{\circ}$. This is because real wage rigidity (a lower ${ }^{\circ}$ ) stabilizes prices, while destabilizing employment and real wages, and this particularly hurts a policymaker which values employment stability. Within our parameter space, the incentive is again mild.

\subsection{Increasing the economy's average performance}

As already mentioned, whenever a reform changes the long-run average output and employment level of the economy, the impact of transitional dynamics on welfare will typically dwarf the contribution of shocks, because shocks are small relative to the output and employment gaps generated by the reform. A corollary is that the optimal

\footnotetext{
${ }^{27}$ Even without having any impact on $\mathrm{q}$ or ${ }^{\circ}$, linear adjustment costs might still have an exect on steady-state employment, but the sign of this exect is highly dependent on certain features of the production function and the distribution function of shocks to it (see B entolila and Bertola, 1990, and B entolila and Saint-Paul, 1994). In our case, labor adjustment costs are implicitly quadratic, so that they clearly have no impact on average employment.
} 
monetary policy will in general be quite dixerent from the steady-state one derived in the previous section.

Consider now the prototypical case of a labor market reform that increases employment in the long run -e.g. reduces the natural rate of unemployment-, namely a reduction in insiders' rents, q. To streamline the discussion, let us limit ourselves to a Neutral government, with no political power of insiders and with equal weights on infation and unemployment (i.e. $1 / 2=0$ and $b=0: 5$ ). Moreover, we only report re sults for two alternative economies, E urope (rigid employment and real wages, ‡exible nominal wages) and the Fully Flexible economy.

To illustrate how monetary policy plays an instrumental role in smoothing the transition to a new steady state following reform, we compare the economy's dynamic response to the reform under EMU to what we get if the optimal monetary policy is followed.

Let us start with the Fully F lexible economy. Figure 1 represents the response of employment and real wages to a reduction in q by 0.1 under EMU (starting from our benchmark of $q=0$ ). Figure 2 plots the corresponding path for the price level. Under EMU, labor market reform puts the economy in a situation similar to a recession in the short run. The initial rate of unemployment is above the natural rate, which has fallen because of the reform. This moderates wages so that employment increases, while the induced moderation in prices creates a strong disin $\ddagger$ ation which boosts competitiveness. The latter allows the economy to absorb the increase in productive capacity, but it is indeed so rapid that employment ends up overshooting the long-run natural rate, and inłation picks up again. Thus, under EMU, labor market reform (or any other shock) induces oscillatory dynamics around the new steady state.

How would monetary policy react if it could be set optimally? Figure 3 plots the optimal response of the nominal exchange rate and the path for the price level absent EMU. The ..rst years of the reform are marked by a rapid depreciation of the exchange rate, which causes the same real depreciation as disinłation did in the previous case, while also bringing the gains of greater price stability. As is apparent in Figure 4, the optimal monetary policy implies a faster real depreciation in the short run than under EMU, while it (almost) avoids the subsequent overshooting of the real exchange rate. This is also true for employment (Figure 5), while the short-run fall in real wages is greater than under EMU since there is much less of a disinłation. Note also that the optimal policy is well approximated by a constant pricelevel rule, which is consistent with bringing employment as quickly as possible to the new natural rate by means of a sharp depreciation. The optimal monetary policy validates the so-called two-handed approach, which claims that aggregate demand stimulus should go along with structural reforms (see Blanchard et al., 1986, and B ean, 1998).

How do these results change for the economy with the labor market con..guration we have called "Europe"? Labor adjustment costs make employment overshooting less severe, but it is still there under EMU and can be eliminated absent EMU (Figure 
6). The optimal monetary policy is still a depreciation, but because of employment's greater inertia, it is less sharp and more spread over time than for the fexible economy (Figure 7). Real wages fall more than in the łexible economy, because a greater fall in labor costs is needed to get the same increase in employment, as labor adjustment costs are higher. It is still true that the real wage drop is greater under the optimal policy than under EMU (Figure 8). Finally, the optimal monetary policy is associated with a slow reduction in the price level, while strong disinfation is observed in the EMU case (Figure 9). Indeed, these simulations imply an in $\neq$ ation dixerential, relative to the longrun value of $1 / 4=0$, of around $-6 \%$ in the short run. If our parametric characterization of the European economy is not wide ox the mark and we take it as a desirable goal to avoid dełation, then this result suggests that the ECB's target in ation rate of $2 \%$ is too low in the sense that any individual country engaging in labor market reform would have a dełation (see Blanchard and Jimeno, 1999, and Gros et al., 1999, for related arguments). One solution to avoid this would be to have a target in ation rate of about $6 \%$ instead of $2 \%$. If this sounds unappealing, it should nevertheless be kept in mind that there is a trade-ox: for any EMU-wide infation rate there exists a maximum level of non-dełationary labor market reform (i.e. a maximum reduction in q). The other solution is a coordinated labor market reform across the Euro countries, with the ECB implementing the optimal monetary policy at the monetary union level. We return to this issue below.

How does EMU membership axect the incentives for reform? If there were no shocks to the economy, then the cost of EMU membership would be zero absent labor market reform. By contrast, it would be strictly positive for an economy that considers reforming its labor market, since EMU precludes implementing the two-handed approach. Things are more complex if there are shocks. In this case, it may be that the optimal policy to accompany the reform oxsets the one that stabilizes shocks, so that less monetary activity is needed under reform than absent reform. If so, EMU membership actually makes reform easier. ${ }^{28}$ This argument is however valid only if the size of shocks is not too small relative to the size of the reform. Otherwise the exect of losing the two-handed approach is dominant. In other words, the reforms that are facilitated by EMU membership are small reforms - of an order of magnitude similar to the typical shock hitting the economy- while large reforms are discouraged. ${ }^{29}$ In the case of the moderate reduction in q by $10 \%$ that we consider here and for the structural parameters we have chosen, our calibrated variance of the shocks is not large enough

\footnotetext{
${ }^{28} \mathrm{~T}$ he issue is as follows. We de..ne optimal policy as a preset response (the $x_{i}$ coet cients) to deviations of variables from their steady-state values. With reform, however, setting a given dynamic path for the exchange rate ewould also be part of the optimal policy. Thus if, for instance, the optimal policy without reform called for an $x_{i}>0$ but with reform it was optimal to have $x_{i}<0$ at a speci..c date, then EMU (e.g. $x_{i}=0$ ) would be less costly with than without reform.

${ }^{29}$ Intuition suggests that similar results to those obtained for a reduction in q would arise for an increase in ${ }^{\circ}$ in a setup with a nonzero $\mathrm{q}$.
} 
for EMU to facilitate reform; the cost of EMU under reform is higher than the cost of EMU absent reform, so that EMU reduces reform incentives. This is illustrated in Table 6.

Note that the negative sign on the dixerential cost I does not necessarily imply that the reverse reform (an increase in q) would become more viable under EMU. A change in any direction would require an activist monetary policy, so that the loss of monetary autonomy reduces the incentives for reform either way. In this sense, EMU need not aggravate Eurosclerosis - if de.. ned as raising q-, but it clearly tends to foster structural inertia.

To illustrate how EMU membership reduces the scope for reform, we have looked at the welfare exects of various sizes of reforms both absent EMU and under EMU, for the same Neutral government. For the "E uropean" economy, assuming an initial rent of $q=0: 1$; the reform which most increases welfare, absent $E M U$, is a reduction in the rent $q$ by $30 \%$, i.e. a move to $q=i 0: 2$. By contrast, under $E M U$ the reform which most increases welfare is a reduction in $q$ by $20 \%$, i.e. a new value equal to $q=i 0: 1$. Furthermore, the gain from reform, in welfare terms, is $8.8 \%$ absent EMU and $6.8 \%$ under EMU. If we assume that there is an upfront cost of implementing the reform, this implies that for a range of this cost (i.e. if it is greater than $6.8 \%$ but smaller than $8.8 \%)$, reform will take place absent EMU but not under EMU.

This result has one important implication. Policymakers of individual EMU member countries considering whether to undertake a labor market reform, so as to achieve lower equilibrium unemployment, will foresee that such reform will also deliver an idiosyncratic, dełationary shock to their economies. EMU implies that monetary policy will not be able to respond to such a shock so as to deliver the best possible transition path to the new equilibrium. Given social preferences and reasonable time-discount factors, the transition path under EMU may just be too costly in terms of welfare, so that reform will not be undertaken in the ..rst place. This proposition is clearly strengthened if societies and/ or policymakers have shorter exective horizons (in other words, a higher discount factor).

Is there a way out of the dilemma? Individual governments might be able to use ..scal, rather than monetary policy, to stimulate demand at the time of a labor reform. This avenue however seems to be severely curtailed by the Stability and Growth Pact (see Eichengreen and W yplosz, 1998). Alternatively, if there was a common agreement for carrying out labor market reforms across all EMU member countries, then the ECB could accompany such reforms with the appropriate monetary policy. This type of behavior is not as far-fetched as it may sound. For instance, in the US the Federal Reserve was willing to adequately relax the monetary policy stance to go along with the severe ..scal consolidation undertaken by the Clinton Administration in the ..rst half of the 1990's (see Blanchard, 1999, p. 92).

An important issue that would need to be addressed at some stage is that dixerent EMU member countries would need dixerent types and intensities of labor market 
reform, and so they would get a correspondingly dixerent dose of a dełationary impact from reform. Trade and ..nance links among countries would also make for asymmetric impacts. While this aspect would need to be considered, it seems much more important that it was widely understood that the overall tone of the ECB's monetary policy would not allow labor market reform to bring about a dełation in any country.

\section{Conclusions}

Most countries belonging to the European Union have experienced persistently high unemployment rate in the last 25 years. The leading explanation attributes this phenomenon to a few key labor market institutions in EU countries. On the other hand, for 11 of the $15 \mathrm{EU}$ countries, the most important institutional change at the turn of the millennium has been the abandoning of national monetary policies in favor of a European Central Bank. A natural and important question to ask is whether this change in the monetary policy regime will either foster or hinder the reform of Euro zone labor markets.

In this paper we analyze this issue in the context of a simple macroeconomic model. We derive optimal, credible monetary policies from the maximization of a social welfare function which takes into account not just long-run equilibrium magnitudes of inłation and unemployment, but also the values of these variables at all times. M ore speci..cally, it takes into account the adjustment path to equilibrium after the economy is hit by supply and demand shocks. We also broaden the standard social welfare function to allow for labor unions to inłuence policy choices by giving an additional preference weight to real wages.

We simulate the model using parameter values taken from estimates in standard macroeconomic models of the labor market and ..nd that the optimal monetary policy varies signi..cantly depending on the labor market institutional setup prevailing in the economy. As a result, those institutions play a key role in determining the welfare losses entailed by giving up an independent national monetary policy. However, such welfare losses also depend on social preferences for inłation, unemployment, and real wages. For instance, while labor adjustment costs seem to decrease welfare as a result of joining EMU, they are more harmful for societies featuring a high degree of inłation aversion and a low political infuence of labor unions. On the other hand, both nominal and real rigidity may even raise welfare as a result of EMU membership, as long as the combination of a low degree of in $\ddagger$ ation aversion and politically powerful unions does not prevail.

Thus, the often-held idea that the more rigidity the higher the cost from joining EMU is an oversimpli..cation, in the sense that it matters what labor institution we are talking about, what are the features of other labor market institutions in the economy, and what are the social preferences. Flexibility is not always a substitute 
for stabilization; it all depends on which variable (e.g. prices vs. employment) society wants to stabilize and which characteristic of the labor market we are talking about.

In the last part of the paper we adopt a dynamic perspective and discuss the incentives for reform inside EMU, as opposed to outside it, by assessing the change in welfare entailed by labor market reform in the two alternatives. We distinguish between reforms that allow for faster adjustment of the economy to shocks, like reductions in nominal wage inertia or in employment inertia, and reforms that alter the economy's long-run performance, like reductions of rents obtained by insider wage setters. We again show how the incentives created by EMU with regard to each institution depend on social preferences. An overall conclusion from our analysis is that it does not seem generally that Eurosclerosis will increase under EMU, in the sense that more rigid institutions will be adopted. But the results clearly indicate that big changes in institutions will be harder to implement. On the other hand, some gradual reforms toward łexibility may be made easier by EMU. O ur main conclusion is therefore that the tendency toward gradualism will be reinforced by EMU membership.

Finally, as argued at various places in the paper, a natural way to regain the bene.ts of an adequate monetary stance along the transition path to a new steady state, following a structural reform, is simply to put together a coordinated reform package across several members of the union, with the ECB implementing the optimal transitional monetary policy at the E uropean level. This allows the two-handed approach to be implemented at the Union level instead of the national level. 


\section{A ppendix 1. How to solve the model}

This appendix provides details on the steps that are needed in order to solve the model. The model's equations are given by:

$$
\begin{aligned}
& y_{t}= \pm\left(e_{t} i \quad p_{t}\right)+{ }_{t} \\
& y_{t}=I_{t}+h+\mu_{t} \\
& p_{t}=w_{t} \text { i } \mu_{t} i h+,\left(I_{t} ; I_{t_{i} 1}\right)+{ }^{-},\left(I_{t} ; \quad E_{t} I_{t+1}\right) \\
& w_{t}=\left(1 ; \quad(q)\left(q+\left(1 ;{ }^{\prime}\right) p_{t}+{ }^{\prime} e_{t}+{ }^{\circ} I_{t}\right)+\circledR\left(w_{t_{i} 1}+p_{t_{i} 1} i p_{t_{i}}\right)\right.
\end{aligned}
$$

and we shall use the notation introduced in the text: $!_{t}=w_{t} i p_{t}$ for the real (product) wage, $x_{t}=e_{t} i \quad p_{t}$ for the real exchange rate, and $1 / 4=p_{t} i \quad p_{t i 1}$ for the in $\neq$ ation rate.

As indicated in the text, the long run values of the model's variables are given by:

$$
\uparrow=\frac{\left( \pm \mathrm{i}^{\prime}\right) \mathrm{h}_{\mathrm{i}} \pm \mathrm{q}}{{ }^{\prime}+{ }^{\circ} \pm} ; \quad !=\mathrm{h} ; \mathrm{x}=\frac{\left(1+{ }^{\circ}\right) \mathrm{h} \mathrm{i} \mathrm{q}}{{ }^{\circ} \pm} ; \text { and } \boldsymbol{y}= \pm \frac{\left(1+{ }^{\circ}\right) \mathrm{h} \text { i q }}{{ }^{\circ} \pm}
$$

The infation rate is equal to the exogenous trend of nominal depreciation, which we assume is equal to zero. Thus, $\mathbf{1} / \mathbf{4}=0$ and the price level is indeterminate unless there is a nominal anchor.

\section{A Optimal monetary policy without a monetary union}

Throughout this appendix we solve only for the case where policymakers can credibly commit on the optimal policy, thereby neglecting the issues highlighted by the credibility literature. We make a change of variable, expressing policy in terms of the real exchange rate rather than the nominal one. Thus policy is characterized by:

$$
\widehat{x_{t}}=x_{0} \hat{⿰}_{t_{1} 1}+x_{1} r_{t_{i} 1}+x_{2}{ }^{2 / x_{t_{i} 1}}+x_{3}{ }^{\prime \prime}{ }_{t}+x_{4} \mu_{t}
$$

The model's equations can be rewritten so that only real variables and the infation rate appear, namely:

$$
\begin{aligned}
& \hat{y_{t}}= \pm \hat{x_{t}}+{ }^{t} \\
& \hat{y_{\mathrm{t}}}=\hat{r_{\mathrm{t}}}+\mu_{\mathrm{t}}
\end{aligned}
$$

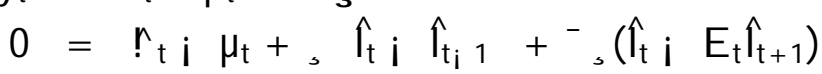

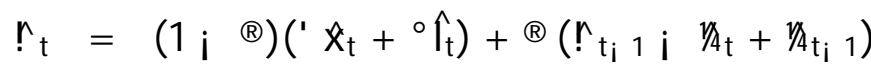


This allows us to solve the system recursively:

$$
\begin{aligned}
& \hat{y_{t}}=y_{0} \hat{t}_{t_{1} 1}+y_{1} r_{t_{i} 1}+y_{2}{ }^{12} x_{t_{1}}+y_{3}{ }^{\prime \prime}+y_{4} \mu_{t} \\
& \hat{r_{t}}=I_{0} \hat{r}_{t_{1} 1}+I_{1} r_{t_{i} 1}+I_{2}{ }^{2} t_{t_{i} 1}+I_{3}{ }^{\prime \prime} t+I_{4} \mu_{t} \\
& r_{t}=!_{0} \hat{t}_{t_{1}}+!_{1} r_{t_{i} 1}+!_{2} 1 t_{t_{i}}+!_{3}{ }^{\prime \prime} t+!_{4} \mu_{t} \\
& 1 / 4=1 / 8 \hat{t}_{i_{1}}+1 / 4 r_{t_{i} 1}+1 / 41 t_{4_{1}}+1 / 4{ }^{\prime \prime} t+1 / 4 \mu_{t}
\end{aligned}
$$

where:

$$
\begin{array}{lll}
\mathrm{y}_{0}=\mathrm{I}_{0}= \pm \mathrm{x}_{0} ; & \mathrm{y}_{1}=\mathrm{I}_{1}= \pm \mathrm{x}_{1} ; & \mathrm{y}_{2}=\mathrm{I}_{2}= \pm \mathrm{x}_{2} \\
\mathrm{y}_{3}=\mathrm{I}_{3}= \pm \mathrm{x}_{3}+1 ; & \mathrm{y}_{4}= \pm \mathrm{x}_{4} ; & \mathrm{I}_{4}= \pm \mathrm{x}_{4} \mathrm{i} 1
\end{array}
$$

and the 10 coet cients $f ! ; ; 1 / 4 g$ are solution to the linear system:

$$
\begin{aligned}
& 0=!_{0} i,+{ }_{0} \pm x_{0}\left(1+{ }^{-}\right) i_{h}{ }^{-},{ }^{h} \pm^{2} x_{0}^{2}+ \pm x_{1} !_{0}+ \pm x_{2}{ }_{i}^{1 / 0} \\
& 0=!_{1}+, \pm x_{1}\left(1+{ }^{-}\right) i- \pm^{2} x_{0} x_{1}+ \pm x_{1} !_{1}+ \pm x_{2}{ }^{1 / 4} i \\
& 0=!_{2}+, \pm x_{2}\left(1+{ }^{-}\right) i^{-}, \pm^{2} x_{0} x_{2}+ \pm x_{1} !_{2}+ \pm x_{2}{ }^{1 / 4} \\
& 0=!_{3}+,\left( \pm x_{3}+1\right)\left(1+{ }^{-}\right) i^{-},\left[ \pm x_{0}\left( \pm x_{3}+1\right)+ \pm x_{1} !_{3}+ \pm x_{2}{ }^{1 / 4}\right] \\
& 0=!_{4} \mathrm{i} 1+,\left( \pm \mathrm{x}_{4} \mathrm{i} 1\right)\left(1++^{-}\right) \mathrm{i}^{-},\left[ \pm \mathrm{x}_{0}\left( \pm \mathrm{x}_{4} \mathrm{i} \quad 1\right)+ \pm \mathrm{x}_{1} !_{4}+ \pm \mathrm{x}_{2}{ }^{1 / 4}\right] \\
& !_{0}=(1 ; \quad \mathbb{B})^{\prime} \mathrm{x}_{0}+(1 ; \mathrm{i})^{\circ} \pm \mathrm{x}_{0} \mathrm{i} \mathbb{B} / \%
\end{aligned}
$$

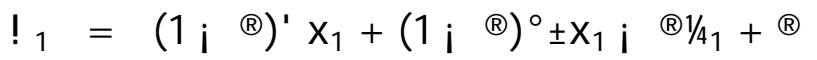

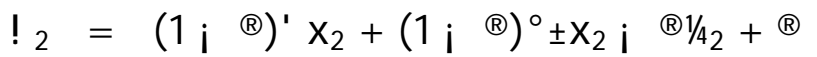

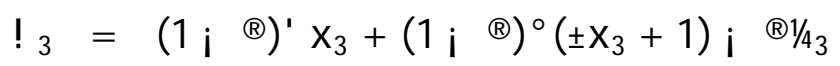

$$
\begin{aligned}
& !_{4}=(1 ; \quad \mathbb{1})^{1} \mathrm{x}_{4}+(1 ; \quad \mathbb{B})^{0}\left( \pm \mathrm{x}_{4}+1\right) ; \quad \mathbb{B} / 4:
\end{aligned}
$$

\section{Welfare}

The next step is to compute the policymaker's welfare function. We de. ne $V\left(\hat{z}_{t_{1}}\right)$ as:

$$
V\left(\hat{t}_{t_{i} 1}\right)=E_{t_{i} 1}{ }_{s=t}^{* 1} \frac{U_{s}}{(1+r)^{(s i t)}}
$$

with $\hat{z_{\mathrm{t}}}=\left(\hat{\Upsilon}_{\mathrm{t}} ; \hat{r}_{\mathrm{t}} ; r_{4}\right)^{0}$ and

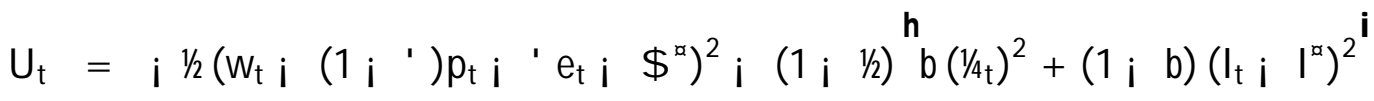

$$
\begin{aligned}
& \left.i^{1 / 2}\left(1 ; i^{\prime}\right) r_{t}+{ }^{\prime} \widehat{x_{t}}+\left(1 i_{3}{ }^{\prime}\right) !+{ }^{\prime} x, \$^{x}\right)^{2} \\
& \text { i }\left(1 ; 1 / A b(1 / 4)^{2}+(1 ; b) r_{t}+\left.r_{i}\right|^{x 2^{2}}\right. \\
& =U\left(\hat{z_{\mathrm{t}}}\right)
\end{aligned}
$$


Developing it, we see that its expectation may be written as:

$$
E_{t_{i} 1} U\left(\hat{z_{t}}\right)=K^{x}+x^{x} \hat{z}_{t_{i} 1}+\hat{z}_{t_{i} 1^{-}}^{0}{ }^{x}{\hat{t_{i}}}_{1}
$$

where:

$$
\begin{aligned}
& \left.\left.K^{x}=i^{1 / 2}\left[\left(1 ; i^{\prime}\right) !+{ }^{\prime} x\right] ; \$^{x}\right)^{2} i^{1 / 2}\left(1 ; i^{\prime}\right) ! !_{3}+{ }^{\prime} x_{3}\right]^{2} 3 / 4
\end{aligned}
$$

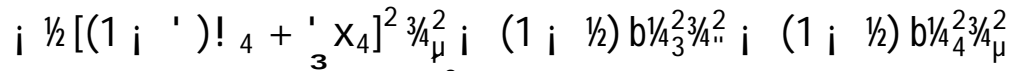

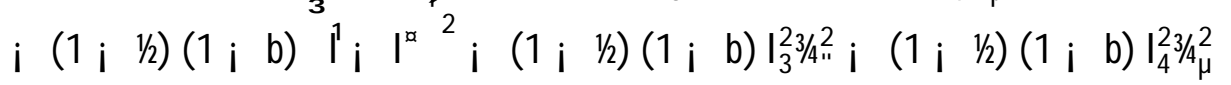

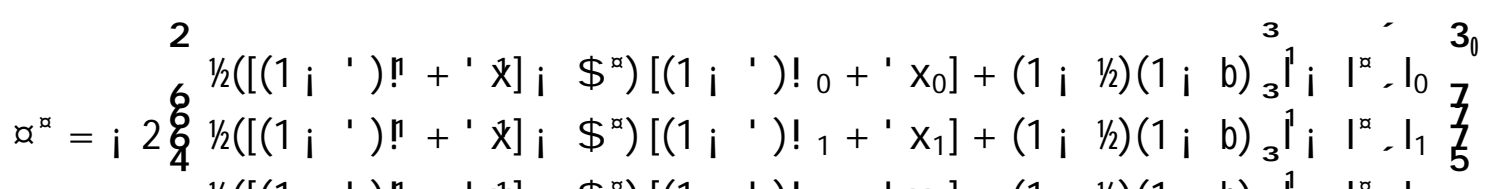

$$
\begin{aligned}
& \left.1 / /\left[\left(1 ;{ }^{\prime}\right) !+{ }^{\prime} x\right] ; \quad{ }^{x}\right)\left[\left(1 ;{ }^{\prime}\right) !{ }_{2}+x_{2}\right]+\left(1 ;\left.{ }^{1 / A}(1 ; b) f^{\prime}\right|^{x} I_{2}\right.
\end{aligned}
$$

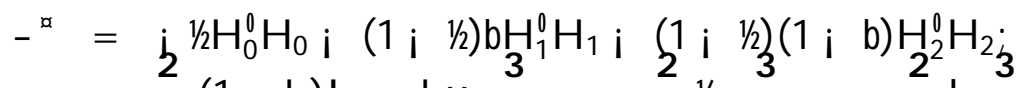

$$
\begin{aligned}
& H_{0}=8\left(1 i^{\prime}\right) ! !_{1}+x^{\prime} x_{0} 7 x_{1} 5 ; H_{1}=6 \frac{1 / 4}{1 / 4} 5 ; H_{2}=6 I_{1} 5 \\
& \left(1 i^{\prime}\right) !_{2}+x_{2} \quad 1 / 4 \quad I_{2}
\end{aligned}
$$

The evolution equation of $\hat{z_{t}}$ is given by:

$$
\hat{\mathrm{z}_{\mathrm{t}}}=\mathrm{M} \hat{\mathrm{z}_{\mathrm{i}} 1}+\mathrm{N}^{\prime}{ }_{\mathrm{t}} ;
$$

where the matrices $\mathrm{M}$ and $\mathrm{N}$ are de. ned as:

$$
M=\begin{array}{rlllll}
2 & I_{0} & I_{1} & I_{2} & 3 \\
4 & 0 & !_{1} & !_{2} & 7 \\
1 / 4 & 1 / 4 & 1 / 4
\end{array} \quad N=\begin{array}{llll}
2 & I_{3} & I_{4} & 3 \\
4 & !_{3} & !_{4} & 5 \\
1 / 4 & 1 / 4
\end{array}
$$

and ${ }_{t}$ is the vector of shocks ${ }_{t}=\left("{ }_{t} ; \mu_{t}\right)^{0}$. V must have the form:

$$
V=K+x \hat{t_{i} 1}+\hat{z_{t_{i}}}-\hat{z_{\mathrm{t}_{1}}}
$$

Using the de..nition of $U$, we can write $V$ in recursive form:

$$
\mathrm{V}\left(\hat{\mathrm{z}_{\mathrm{t}} 1}\right)=\mathrm{E}_{\mathrm{t}_{\mathrm{i}} 1} \mathrm{U}\left(\hat{\mathrm{z}_{\mathrm{t}}}\right)+\frac{1}{1+\mathrm{r}} \mathrm{E}_{\mathrm{t}_{\mathrm{i}} 1} \mathrm{~V}\left(\hat{\mathrm{z}_{\mathrm{t}}}\right)
$$

This can be conveniently rewritten as:

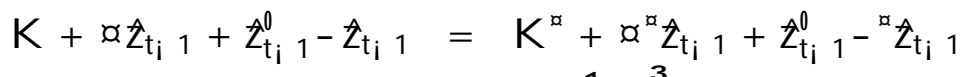

$$
\begin{aligned}
& +\frac{1}{1+r}^{3} K+x M \hat{z_{t_{i}}}+\hat{z}_{t_{i} 1}^{0} M^{0}-M \hat{z_{t_{i}}}+N^{\stackrel{0}{-}} N^{-} \S
\end{aligned}
$$


where $\S=\mathrm{E}^{\prime \prime}{ }^{0}$ and ${ }^{-}$denotes the scalar product of two matrices: $\mathrm{A}^{-} \mathrm{B}=\S_{\mathrm{i} ; \mathrm{j}} \mathrm{a}_{\mathrm{ij}} \mathrm{b}_{\mathrm{ij}}$.

The latter equation must hold for all $\hat{z}$, which allows us to compute $K, x$, and - :

$$
a=x^{x}\left(1 ; \frac{1}{1+r} M\right)^{i 1}
$$

As for - ; it must be a solution to:

$$
-=-{ }^{x}+\frac{1}{1+r} M^{0}-M
$$

Forward integration allows us to ..nd the solution:

$$
-={ }_{k=0}^{*^{1}} \frac{M^{a_{-}}{ }^{x} M^{k}}{(1+r)^{k}}
$$

Finally, by equating constant terms we get $\mathrm{K}$ :

$$
K=\frac{1+r}{r} K^{a}+\frac{1}{r} N^{0}-N^{-} \S
$$

\section{B Equilibrium with a monetary union}

In the EMU case we cannot rewrite the model in terms of $x ;$ ! ; and $1 / 4$ Instead we have to use a four-dimensional system in $(\hat{\Upsilon} ; r ; 17 / 4 \hat{p})$. Belonging to $E M U$ forces an economy to have a nominal anchor and it therefore precludes the real exchange targeting which is optimal absent E MU. Thus $\hat{p}$ reappears since the real exchange rate is, by de..nition, given by $x=i p$. Let $\widehat{v}_{t}=\left(\widehat{r}_{t} ; r_{t} ; r_{t} ; \hat{p_{t}}\right)^{0}$. Then it follows that:

$$
\widehat{v}_{t}=A \widehat{v}_{t_{i}}+B E_{t} \widehat{v}_{t+1}+C^{\prime}{ }_{t}
$$

where:

$$
\begin{aligned}
& A=Q^{i 1} A^{2} ; B=Q^{i}{ }^{1} B ; C=Q^{i}{ }^{1} C
\end{aligned}
$$

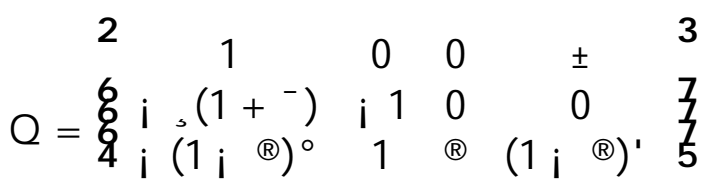

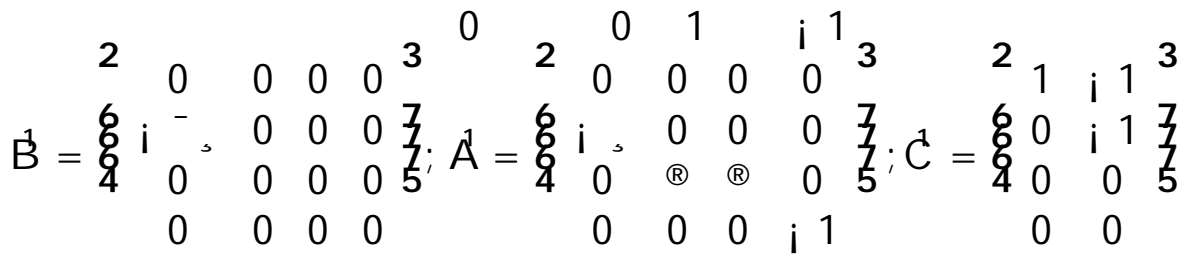


This system has the following solution:

$$
\hat{v}_{t}=M^{E} \hat{v}_{t_{i}}+N^{E}{ }_{t}
$$

where $M$ is solution to

$$
M M^{E} i B^{3} M^{E^{\prime}}{ }^{2}=A
$$

and $\mathrm{N}$ is given by

$$
N^{E}=\left(I ; B M^{E}\right)^{i}{ }^{1} C:
$$

\section{Welfare}

To compute welfare we use the same steps as in the non-EMU case. However, let us do it with a more compact notation. Equation (9) can be written as:

$$
U_{t}=U_{0}+U_{1} \widehat{v}_{t}+v_{t} U_{2} \widehat{v}_{t}
$$

where:

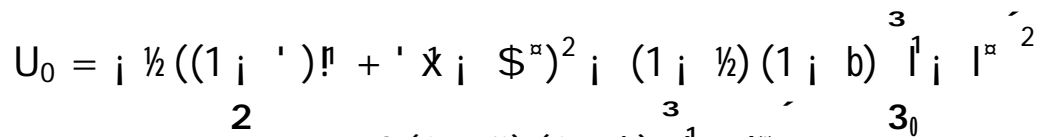

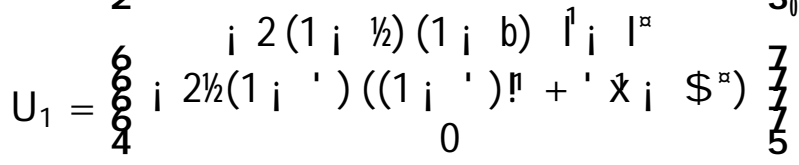

$$
\begin{aligned}
& 2^{1 / 2}\left(\left(1 i^{\prime}\right) !+{ }^{\prime} \times{ } \$^{x}\right)
\end{aligned}
$$

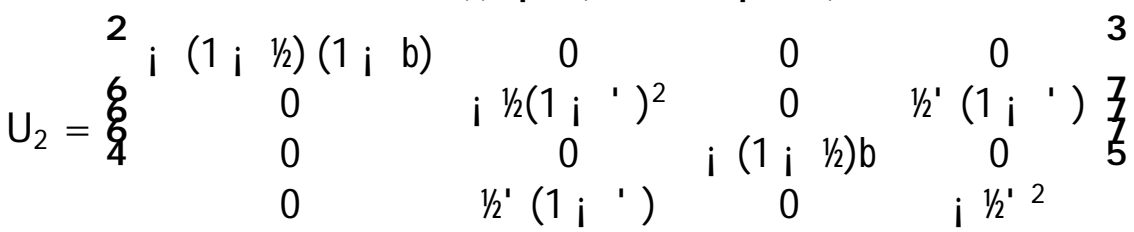

We now have:

$$
U\left(\widehat{v}_{t}\right)=K^{x E}+x^{x E} \widehat{v}_{t_{i} 1}+v_{t_{i} 1^{-}}^{0}{ }^{x E} \widehat{v}_{t_{i}}
$$

where:

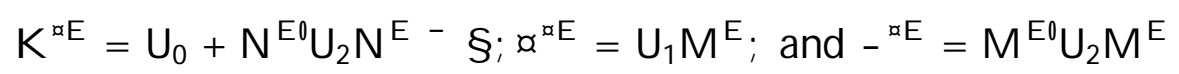

$\checkmark$ must now be of the form:

$$
V^{E}=K^{E}+x^{E} \hat{t_{i} 1}+z_{t_{i} 1^{-}}^{D} \hat{z_{t_{i} 1}}
$$

Hence:

$$
\begin{aligned}
& K^{E}+x^{E} \widehat{v}_{t_{i} 1}+v_{t_{i} 1^{-}}^{0}{ }^{E} \widehat{v}_{t_{i} 1}=K{ }^{x E}+x_{A}^{x E} \widehat{v}_{t_{i} 1}+v_{t_{i} 1^{-}}^{0}{ }^{x E} \widehat{v}_{t_{i} 1}
\end{aligned}
$$

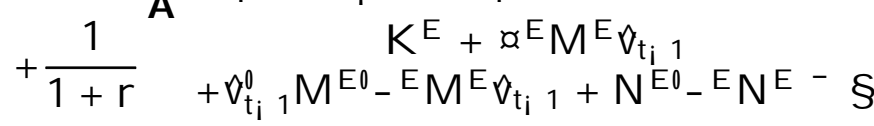


Hence:

$$
\begin{gathered}
\alpha^{E}=\alpha^{E x}\left(I ; \frac{1}{1+r} M^{E}\right)^{i 1} \\
-E={ }_{k=0}^{* 1} \frac{M^{E K_{-}{ }^{x} M} M^{E k}}{(1+r)^{k}} ; \text { and } K^{E}=\frac{1+r}{r} K^{x E}+\frac{1}{r} N^{E 0}{ }^{E} N^{E-} \S
\end{gathered}
$$




\section{A ppendix 2. Calibration of parameters}

\section{A Labor market parameters}

Layard, Nickell, and J ackman (1991), hereafter LNJ, estimate for 19 OECD countries over the period 1969-85 the following price and wage equations:

$$
\begin{aligned}
& p_{t} ; \quad w_{t}=\left(1 ;{ }^{-9}\left(p_{t_{i} 1} ; \quad w_{t_{i} 1}\right)+{ }^{-}{ }_{0} i^{-}{ }_{1} u_{t} i^{-}{ }_{11} \phi u_{t} i^{-}{ }_{2} \phi^{2} p_{t}\right. \\
& w_{\mathrm{t}} \mathrm{i} p_{\mathrm{t}}=\left(1 \mathrm{i} \circ \mathrm{\circ}\left(\mathrm{w}_{\mathrm{t}, 1} 1 \mathrm{i} p_{\mathrm{t}_{\mathrm{i}} 1}\right)+{ }^{\circ}{ }_{0} \mathrm{i}^{\circ}{ }_{1} u_{\mathrm{t}} \mathrm{i}^{\circ}{ }_{11} \notin \mathrm{u}_{\mathrm{t}} \mathrm{i}^{\circ}{ }_{2} \phi^{2} p_{\mathrm{t}}\right.
\end{aligned}
$$

where $u_{t}$ denotes the unemployment rate and the remaining symbols are as in the text. Long-run parameters are given by ${ }^{-}{ }_{\mathrm{i}}={ }^{-}{ }_{\mathrm{i}}=1 \mathrm{i}_{\mathrm{i}}{ }^{-9}$ and ${ }^{{ }_{\mathrm{i}}}={ }_{\mathrm{i}}=11 \mathrm{i} \quad \mathrm{0}$, for $\mathrm{i}=0 ; 1 ; 2$.

In order to employ their estimated parameters we need to match these equations to our own price and wage equations, repeated here for convenience:

$$
\begin{aligned}
& p_{t}=w_{t} i \mu_{t} i h+,\left(I_{t} I_{t_{i} 1}\right)+{ }^{-},\left(I_{t} i E_{t} I_{t+1}\right) \\
& w_{t}=(1 ; @)\left(q+\left(1 ;{ }^{\prime}\right) p_{t}+{ }^{\prime} e_{t}+{ }^{\circ} I_{t}\right)+\&\left(w_{t_{i} 1}+p_{t_{i} 1} i p_{t_{i} 2}\right)
\end{aligned}
$$

The correspondence of parameters is established by the variables they are attached to, but also by the fact that LNJ provide favorable evidence obtained from simple cross-section regressions of the country-speci..c coec cients on several proxies for the institutional arrangements which should explain them according to the theory.

A. Our parameter for labor adjustment costs, , , corresponds to ${ }^{-}{ }_{11}$, the hysteresis parameter in the price equation. LNJ present a cross-country regression (p. 420) where ${ }^{-}{ }_{11}$ is found to be correlated with the share of manufacturing employees with short tenure (negatively) and with measures of severance pay and notice periods (positively). The latter two were not signi..cant, but we have estimated a regression of the same coeø cients on a newly constructed employment protection variable taken from Blanchard and Wolfers (1999) obtaining a positively-signed coec cient with a t-ratio of 3.4 .

B. O ur parameter for real wage $\ddagger$ exibility, ${ }^{\circ}$, corresponds to ${ }_{1}^{\circ}$, the long-run exect of unemployment on the real wage. In a cross-country regression (p. 418) ${ }_{1}$ is found to be correlated with unemployment bene..t duration, replacement rates, and dummy variables for corporatism (negatively), and with the share of manufacturing employees working in small ..rms and dummy variables for employer and union coordination (positively).

C. Our parameter for nominal wage inertia, ${ }^{\circledR}$, corresponds to $1 \mathrm{i}^{\circ} 0$, the inertia parameter in the wage equation. This is easily seen by realizing that setting ' $=0$ our wage equation can be rewritten as:

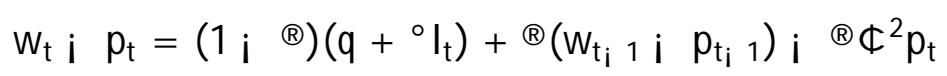


While straightforward, this bears clari..cation because LNJ actually call ${ }_{2}$ the nominal wage rigidity parameter. Of course, in our model ${ }_{2}^{\circ}$ and $1 i^{\circ}{ }^{0}$ coincide. LNJ present cross-section estimates (p. 429) where ${ }_{2}^{\circ}$ is found to be negatively correlated with the variance of the growth rate of nominal GDP and a dummy variable for the length of wage contracts, as well as with dummy variables for the degree of indexation and synchronization of wage contracts (the latter two are not signi..cant). We have performed the same regression on the coec cient $1 i^{\circ} 0$, obtaining similar results.

How do we arrive at the values characterizing rigid and $\ddagger$ exible institutions? We computed the means for the countries ranked in positions 2 to 7 , from highest to lowest, for the rigid value, and those ranked 13 to 18 for the $\ddagger$ exible value (respectively $\ddagger$ exible and rigid values, in the case of ${ }^{\circ}$ ). This rule was chosen to leave out potential outliers (countries ranked in positions 1 and 19) and to leave some room in between (countries ranked 8 to 12). To check the robustness of the parameter values, we applied the same procedure to the estimates on similar parameters obtained in three other papers on varying sample periods and countries: Alogoskou..s and Manning (1988), Grubb (1986), and Newell and Symons (1985) (as reported in LNJ , pp. 454-466).

Table A 1 provides a comparison of estimates. The last column contains our consensus estimate. T wo features are worth noting. $F$ irst, the values are quite consistent across studies. Second, the rankings across countries are not very coincidental, as indicated by the low correlation coed cients shown for each parameter.

\section{B Other parameters}

Demand and supply shock variances ( $3 / 4$ and $3 / 4$ ). We adopt the estimates from Bayoumi and Eichengreen (1993). They estimate a bivariate VAR on GDP growth and in $\ddagger$ ation. Supply and demand shocks are independent by construction. Supply shocks are allowed to have permanent exects on output levels, while demand shocks are not. B oth have permanent exects on the level of prices. They use annual data on 11 EU countries over the period 1960-88. Estimated standard deviations for supply and demand shocks are quite similar across countries, both having average values around $2 \%$. For supply the estimates range from $1.2 \%$ (France) to 3\% (Greece) and for demand from $1.4 \%$ (Germany) to $3.4 \%$ (Ireland).

Reduction in demand shock variance (3/4) due to EM U. Canzoneri et al. (1996) estimate a VAR for each of 6 OE CD countries (A ustria, the Netherlands, France, Italy, Spain and the United K ingdom) vis-a-vis Germany, in output, public spending, and the exchange rate, and allow for three types of shocks: supply, government spending and money/..nance. They ..nd that money shocks explain on average 33\% of the variance of output which is due to aggregate demand shocks (i.e. government spending plus money/ ..nance) over a one-year period. 
Open economy parameters. The real exchange elasticity \pm is computed as the weighted average of the long-run estimated elasticities of exports and imports of manufactured goods with respect to the real exchange, using export and import ratios as weights. This is then multiplied by the manufacturing share in GDP plus one-half times the complementary share (since the remaining sectors, notably services, are less open than manufacturing). The estimated elasticities are for France, Germany, Italy, and the UK, from A rtus and K night (1984) and correspond to the period 1980-1985. The price weight ' is simply calibrated by the share of imports in GDP from the OECD E conomic Outlook. These calculations yield a value of $\pm={ }^{\prime}=0: 2$.

In‡ation preference parameter (b). There is surprisingly little evidence on the weights of in ation and unemployment in the central bank's objective function as captured in the B arro-Gordon (1983) framework. For the US, some estimates (Favero and Rovelli, 1999) and calibrations (Rotemberg and Woodford, 1997) suggest that the weight of unemployment might actually be zero. Broadbent and Barro (1997), on the other hand, ..nd that output surprises have a weight of about one-third as high as the infation variance. The most comprehensive analysis so far has been carried out by Lippi (1998, ch. 8), who estimates the objective function for 49 countries over the period 1965-1992. Transforming his estimates to our metric -they are in terms of output, rather than employment deviations, and so we use (the inverse of) a common labor share of 0.67 in the transformation), the estimated value for the in $¥$ ation weight, b, is 0.63 (s.e. $=0.25)$, while for $22 \mathrm{OECD}$ countries it is $0.74(\mathrm{~s} . \mathrm{e} .=0.18)$. 
Table A 1. Comparison of estimates of rigid and ‡exible parameters.

\begin{tabular}{|c|c|c|c|c|c|}
\hline Parameters & $\begin{array}{l}\text { Layard } \\
\text { et al. }\end{array}$ & $\begin{array}{l}\text { Newell- } \\
\text { Symons }\end{array}$ & Grubb & $\begin{array}{l}\text { A logosk.- } \\
\text { Manning }\end{array}$ & Consensus \\
\hline \multicolumn{6}{|c|}{ Labor adjustment costs $()}$, \\
\hline Rigid & 8.1 & 10.9 & - & - & 8.00 \\
\hline Flexible & 1.0 & 2.1 & - & - & 1.00 \\
\hline Maximum & 14.4 & 18.2 & - & - & \\
\hline Minimum & -0.2 & 0.2 & - & - & \\
\hline Correlation with LNJ & 1.0 & 0.39 & - & - & \\
\hline \multicolumn{2}{|l|}{ Real wage $\ddagger$ exibility $\left({ }^{\circ}\right)$} & & & - & \\
\hline Rigid & 1.2 & 0.7 & 0.9 & 1.0 & 1.25 \\
\hline Flexible & 8.6 & 4.5 & 2.5 & 8.1 & 4.00 \\
\hline Maximum & 14.5 & 7.2 & 6.5 & 123.0 & \\
\hline Minimum & 0.7 & 0.0 & 0.3 & 1.1 & \\
\hline Correlation with LNJ & 1.0 & 0.78 & 0.36 & 0.37 & \\
\hline \multicolumn{6}{|c|}{ Nominal wage inertia ( $($ ) } \\
\hline Rigid & 0.82 & 0.80 & - & 0.96 & 0.80 \\
\hline Flexible & 0.46 & 0.51 & - & 0.72 & 0.45 \\
\hline Maximum & 0.94 & 0.86 & - & 0.98 & \\
\hline Minimum & 0.00 & 0.32 & - & 0.56 & \\
\hline Correlation with LNJ & 1.0 & 0.27 & - & 0.22 & \\
\hline
\end{tabular}

Note: Correlation coed cients calculated with the subsamples of countries which overlap with the ones included in Layard et al. (1991). 


\section{A ppendix 3. Further simulation results}

Table A2. Exect of EMU on the variance of employment, prices, and real wages for dixerent labor institutions (\%).

\begin{tabular}{|c|c|c|c|c|c|c|}
\hline Labor Institutions & & \multicolumn{4}{|c|}{ Employ- } & $\begin{array}{c}\text { Real } \\
\text { wages }\end{array}$ \\
\hline Fully Rigid & $\mathrm{R}$ & $\mathrm{R}$ & $\mathrm{R}$ & 0.1 & 26.8 & 17.5 \\
\hline Rigid Wage & $\mathrm{F}$ & $\mathrm{R}$ & $\mathrm{R}$ & 0.5 & 5.8 & 3.6 \\
\hline Scandinavia & $\mathrm{R}$ & $\mathrm{F}$ & R & 0.1 & 27.0 & 17.2 \\
\hline United States & $\mathrm{F}$ & $\mathrm{F}$ & R & 0.5 & 7.1 & 3.5 \\
\hline Europe & $\mathrm{R}$ & $\mathrm{R}$ & $\mathrm{F}$ & 0.0 & 31.8 & 10.8 \\
\hline United K ingdom & $\mathrm{F}$ & $\mathrm{R}$ & $\mathrm{F}$ & 0.3 & 11.9 & 3.2 \\
\hline J apan & $\mathrm{R}$ & $\mathrm{F}$ & $\mathrm{F}$ & 0.0 & 32.1 & 9.8 \\
\hline Fully Flexible & $\mathrm{F}$ & $\mathrm{F}$ & $\mathrm{F}$ & 0.2 & 15.6 & 3.0 \\
\hline A verage & & & & 0.2 & 19.8 & 8.6 \\
\hline \multicolumn{7}{|c|}{ Labor adjustment costs (, ) } \\
\hline Rigid & & & & 0.1 & 29.4 & 13.8 \\
\hline Flexible & & & & 0.4 & 10.1 & 3.3 \\
\hline Dixerence Rigid-F & xi & & & -0.3 & 19.3 & 10.5 \\
\hline \multicolumn{7}{|c|}{ Real wage $\ddagger$ exibility $\left({ }^{\circ}\right)$} \\
\hline Rigid & & & & 0.2 & 19.0 & 8.8 \\
\hline Flexible & & & & 0.2 & 20.5 & 8.4 \\
\hline Dixerence Rigid-F & $x i$ & & & 0.1 & -1.4 & 0.4 \\
\hline \multicolumn{7}{|c|}{ Nominal wage inertia ( $($ ) } \\
\hline Rigid & & & & 0.3 & 16.7 & 10.5 \\
\hline Flexible & & & & 0.1 & 22.9 & 6.7 \\
\hline Diperence Rigid-F & exil & & & 0.2 & -6.2 & 3.8 \\
\hline
\end{tabular}

Note. The ..rst column is found by setting $1 / 2=0$ and $b=0$, the second one by setting $1 / 2=0$ and $b=1$, and the third one by setting $1 / 2=1$. The bottom panel reports the average cost for the 4 countries which share the indicated characteristic. Other parameters: ${ }^{-}=0: 9 ; r=0: 1 ; 3 / 4=3 / 4=0: 0004 ; q=0$. 
Table A 3. Exect of labor market institutions and political preferences on the cost of EMU with reduced demand uncertainty (\%).

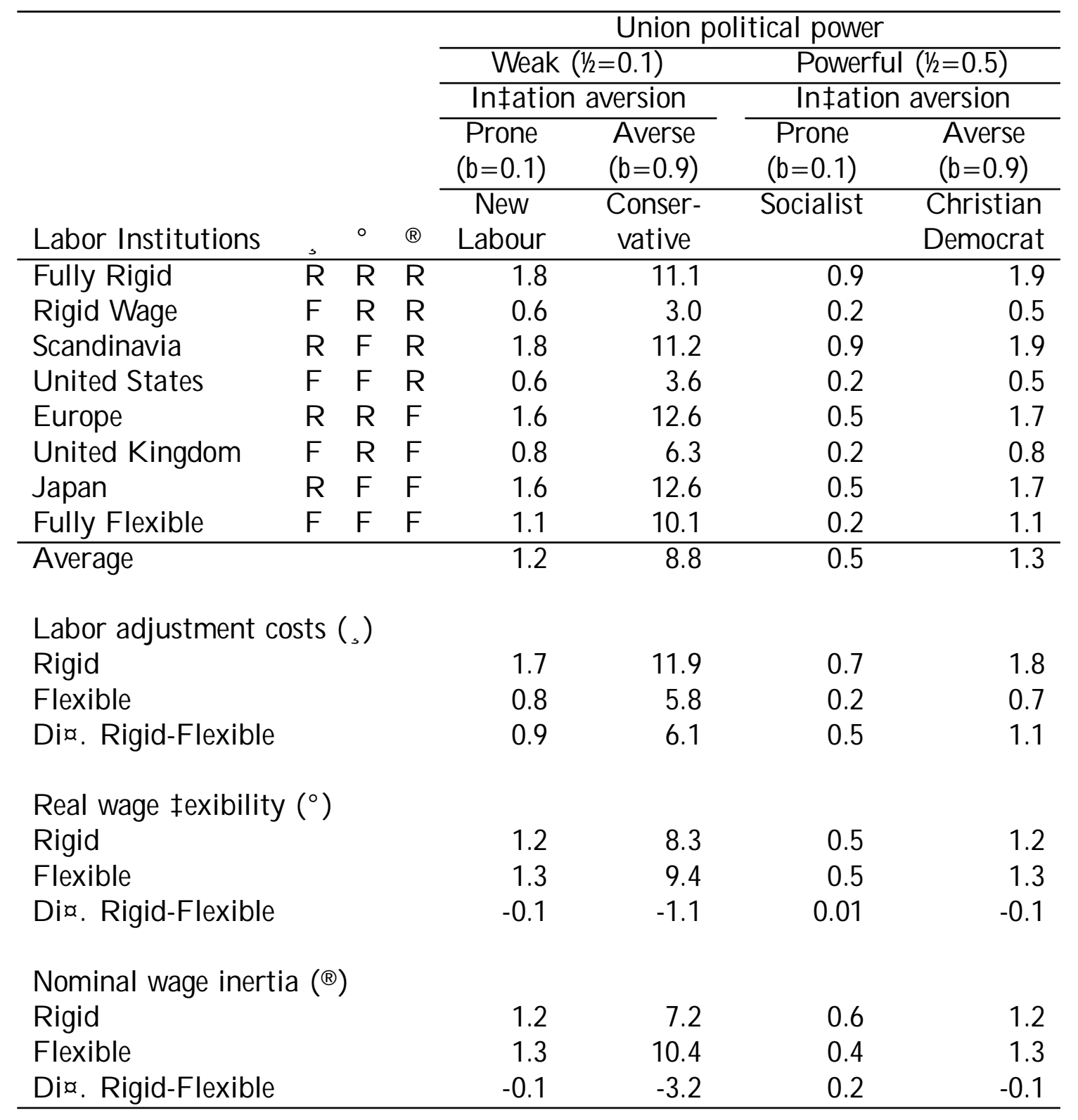

Notes. The cost of EMU measures the welfare cost, according to welfare function (5) in the text, of moving from the optimal parameters $x_{i}$ to $x_{i}=0$ for all $i$. All costs are normalized by the steady-state welfare corresponding to the speci..c political preference parameter pair and in percentage terms. The bottom panel reports the average cost for the 4 countries which share the indicated characteristic. Other parameters: ${ }^{-}=0: 9$; $r=0: 1 ; 3 / 4=0: 00027 ; 3 / 4=0: 0004 ; q=0$. 


\section{R eferences}

A kerlof, G., R. Dickens and G. Perry (1996), "T he M acroeconomics of Low Inłation", B rookings Papers on Economic Activity.

Alogoskou..S, G. and A. Manning (1988), "On the Persistence of Unemployment", E conomic Policy.

A ndersen, T. and J .-R. Sorensen (1993), "W ill Product Market Integration Lower Unemployment?", in Fagerberg and Lundberg, eds., European Economic Integration: A Nordic Perspective, Aldershot, B rook..eld, Vt. (UK).

Artus, J . and M. K night (1984), "Issues in the A ssessment of the Exchange Rates of Industrial Countries, International Monetary Fund", Occasional Paper 29.

Broadbent B. and R. Barro (1997), "Central Bank Preferences and Macroeconomic Equilibrium", J ournal of M onetary Economics.

Barro, R. and D. Gordon (1983), "A Positive Theory of M onetary Policy in a Natural Rate Model", J ournal of Political E conomy.

Bayoumi, T. and B. Eichengreen (1993), "Shocking A spects of European M onetary Integration", in Torres and Giavazzi, eds., Adjustment and Growth in the EMU, Cambridge University Press, Cambridge.

Bean, C. (1992), "E conomic and Monetary Union in E urope", J ournal of E conomic Perspectives.

B ean, C. (1998), "T he Interaction of A ggregate Demand Policies and Labor Market Reform", Swedish Review of Economic Policy.

Bean, C., S. Bentolila, G. Bertola, and J. Dolado (1998), Social Europe: One for All?, Monitoring European Integration 8, Centre for E conomic Policy R esearch, London.

Bentolila, S. and G. Bertola (1990), "Firing Costs and Labor Demand: How Bad is Eurosclerosis?", Review of Economic Studies.

Bentolila, S. and G. Saint-Paul (1994), "A Model of Labor Demand with Linear Ajustment Costs", Labour Economics.

Bertola, G. and A. Ichino (1995), "Crossing the River: A Comparative Perspective on Italian Employment Dynamics", Economic Policy.

Bewley, T. (1998), "W hy Not Cut Pay?", European Economic Review. 
Blanchard, O. (1999), Macroeconomics, 2nd. ed., Prentice-Hall, New J ersey.

Blanchard, O., R. Dornbusch, J. Drèze, H. Giersch, R. Layard, and M. M onti (1986), "E mployment and Growth in Europe: A T wo-Handed Approach", in Blanchard et al., eds., Restoring Europe's Prosperity, MIT Press, Cambridge, MA.

Blanchard, O. and J . J imeno (1999), "Reducing Spanish Unemployment under the EMU", FEDEA, Working Paper 1999-02.

Blanchard, O. and L. Summers (1986), "Hysteresis and the European Unemployment Problem", NBER Macroeconomics Annual, MIT Press, Cambridge, MA.

Blanchard, O. and J. Wolfers (1999), "The Role of Shocks and Institutions in the Rise of E uropean Unemployment: The A ggregate E vidence", mimeo (http:// web. mit.edu/blanchar/www/ harry.pdf).

Bruno, M. and J. Sachs (1985), The Economics of Worldwide Stagłation, Harvard University P ress, Harvard.

Burda, M. (1999), "European Labour Markets and the Euro: How Much Flexibility Do We Really Need?", Centre for Economic Policy Research Discussion Paper 2217.

Calmfors, L. (1998), "M acroeconomic Policy, Wage Setting and Employment - What Dixerence Does E MU Make?", Oxford Review of Economic Policy.

Calmfors, L. and J . Driф II (1988), "Centralisation of Wage Bargaining and Macroeconomic Performance", Economic Policy.

Calmfors, L. et al. (1997). EMU - A Swedish Perspective, K luwer A cademic Publishers, Dordrecht, NL.

Calvo, G. (1983), "Staggered Prices in a Utility-Maximizing Framework", J ournal of M onetary Economics.

Canzoneri, M., J . Viñals, and J . Vallés (1996), "Do Exchange Rates M ove to Address International M acroeconomic Imbalances?", Centre for E conomic Policy Research Discussion Paper 1498.

Chirinko, R. (1993), "Business Fixed Investment Spending: M odeling Strategies, Empirical Results, and Policy Implications", J ournal of E conomic Literature.

Commission of the European Communities (1990), "One Market, One M oney", European E conomy. 
Cukierman, A and F . Lippi (1999), "Labor M arkets and M onetary Union: A Strategic A nalysis", Centre for Economic Policy Research Discussion Paper 2236.

Danthine, J.-P. and J. Hunt (1994), "Wage Bargaining Structure, Employment and E conomic Integration", Economic J ournal.

Eichengreen, B. and C. Wyplosz (1998), "The Stability Pact. More than a Minor Nuisance?", E conomic Policy.

Erceg, C., D. Henderson, and A. Levin, "Optimal Monetary Policy with Staggered Wage and Price Contracts", Board of Governors of the Federal Reserve System, International Finance Discussion Papers 640.

Favero, C. and R. Rovelli (1999), "Modelling and Identifying Central Banks' Preferences", Centre for Economic Policy Research Discussion Paper 2178.

Gottfries, N. and H. Horn (1986), "Wage Formation and the Persistence of Unemployment", E conomic J ournal.

Gros, D., O. Blanchard, M. Emerson, T. Mayer, G. Saint-Paul, H.-W. Sinn, and G. Tabellini (1998), Macroeconomic Policy in the First Year of Euroland, First A nnual Report of the CEPS Macroeconomic Policy Group, Centre for Economic Policy Studies, Brussels.

Grubb, D. (1986), "Topics in the OECD P hillips Curve", Economic J ournal.

Layard, R., S. Nickell, and R. J ackman (1991), Unemployment. M acroeconomic Performance and the Labour Market, Oxford University Press, Oxford.

Lindbeck, A . and D. Snower (1988), The Insider-O utsider Theory of E mployment and Unemployment, MIT Press, Cambridge, MA.

Lippi, F . (1998), Central B ank Independence, Targets and Credibility, Edward Elgar, Cheltenham, UK.

Muellbauer, J . (1993), "The A ssessment: Consumer Expenditure", Oxford Review of Economic Policy.

Mundell, R. (1961), "The Theory of Optimal Currency Areas", American Economic Review.

Newell, A . and J. Symons (1985), "Wages and Employment in OECD Countries", London School of Economics, Centre for Labour Economics, Discussion Paper 219. 
Nickell, S. (1997), "Unemployment and Labor M arket Rigidities: Europe versus North A merica", J ournal of E conomic Perspectives.

Obstfeld, M. and K. Rogox (1997), Foundations of International Macroeconomics, MIT Press, Cambridge, MA.

Rose, A. (2000), "One Money, One Market: Estimating the Exect of Common Currencies on Trade", Economic Policy.

Rotemberg, J and M . Woodford (1997), "An O ptimization-B ased Econometric Framework for the Evaluation of Monetary Policy", NBER Macroeconomics Annual 1997, MIT Press, Cambridge, MA.

Saint-Paul, G. (1996), "Exploring the Political Economy of Labour Market Institutions, Economic Policy.

Saint-Paul, G. and E. Wasmer (1999), "Labor Market Policies: Strategic Games between National Governments and the European Central Bank", in P.Magnette and $\mathrm{E}$. Remacle, eds., The New European M odel between integration and decentralization, Institut d'Etudes Européennes, B russels.

Sibert, A. and A. Sutherland (1998), "M onetary Regimes and Labour Market Reform", CEPR Discussion Paper 1731.

Andersen, T ., N. Haldrup, and J . Sørensen (2000), "P roduct Market Integration and E uropean Labour Markets", E conomic Policy.

Taylor, J . (1980), "Aggregate Dynamics and Staggered Contracts", J ournal of Political E conomy.

Viñals, J . and J . J imeno (1998), "T he Impact of E MU on European Unemployment", EIB Papers, European Investment Bank.

Wyplosz, C. (1997), "EMU: Why and How It Might Happen", J ournal of Economic Perspectives. 
Table 1. Parameter set for labor market institutions.

\begin{tabular}{|c|c|c|c|}
\hline \multirow[b]{3}{*}{ Degree of $\ddagger$ exibility } & \multicolumn{3}{|c|}{ Labor market institutions } \\
\hline & $\begin{array}{l}\text { Labor } \\
\text { adj. costs }\end{array}$ & $\begin{array}{l}\text { Real wage } \\
\text { fexibility }\end{array}$ & $\begin{array}{c}\text { Nominal } \\
\text { wage inertia }\end{array}$ \\
\hline & $()$, & $\left({ }^{\circ}\right)$ & (®) \\
\hline Rigid & 8.00 & 1.25 & 0.80 \\
\hline Flexible & 1.00 & 4.00 & 0.45 \\
\hline
\end{tabular}

Note: Values chosen according to several empirical studies (see A ppendix 2).

Table 2. Virtual economies according to parameter con..gurations for labor market institutions.

\begin{tabular}{lccc}
\hline & \multicolumn{3}{c}{ Labor market institutions } \\
\cline { 2 - 4 } & $\begin{array}{c}\text { Labor } \\
\text { adj. costs } \\
\text { Country }\end{array}$ & $\begin{array}{c}\text { Real wage } \\
\text { †exibility } \\
\left({ }^{\circ}\right)\end{array}$ & $\begin{array}{c}\text { Nominal } \\
\text { wage inertia } \\
(\circledast)\end{array}$ \\
\hline Fully Rigid & $\mathrm{R}$ & $\mathrm{R}$ & $\mathrm{R}$ \\
Rigid Wages & $\mathrm{F}$ & $\mathrm{R}$ & $\mathrm{R}$ \\
Scandinavia & $\mathrm{R}$ & $\mathrm{F}$ & $\mathrm{R}$ \\
United States & $\mathrm{F}$ & $\mathrm{F}$ & $\mathrm{R}$ \\
Europe & $\mathrm{R}$ & $\mathrm{R}$ & $\mathrm{F}$ \\
United Kingdom & $\mathrm{F}$ & $\mathrm{R}$ & $\mathrm{F}$ \\
J apan & $\mathrm{R}$ & $\mathrm{F}$ & $\mathrm{F}$ \\
Fully Flexible & $\mathrm{F}$ & $\mathrm{F}$ & $\mathrm{F}$ \\
\hline
\end{tabular}

Table 3. Space generated by policy preference parameters.

\begin{tabular}{lcc}
\hline & \multicolumn{2}{c}{ In¥ation aversion } \\
\cline { 2 - 3 } Union political power & Prone & A verse \\
Weak $(1 / 2=0: 1)$ & New Labour & $(b=0: 9)$ \\
Strong $(1 / 2=0: 5)$ & Socialist & Christian Dervative \\
\hline
\end{tabular}


Table 4. Exect of labor market institutions and political preferences on the cost of EMU (\%).

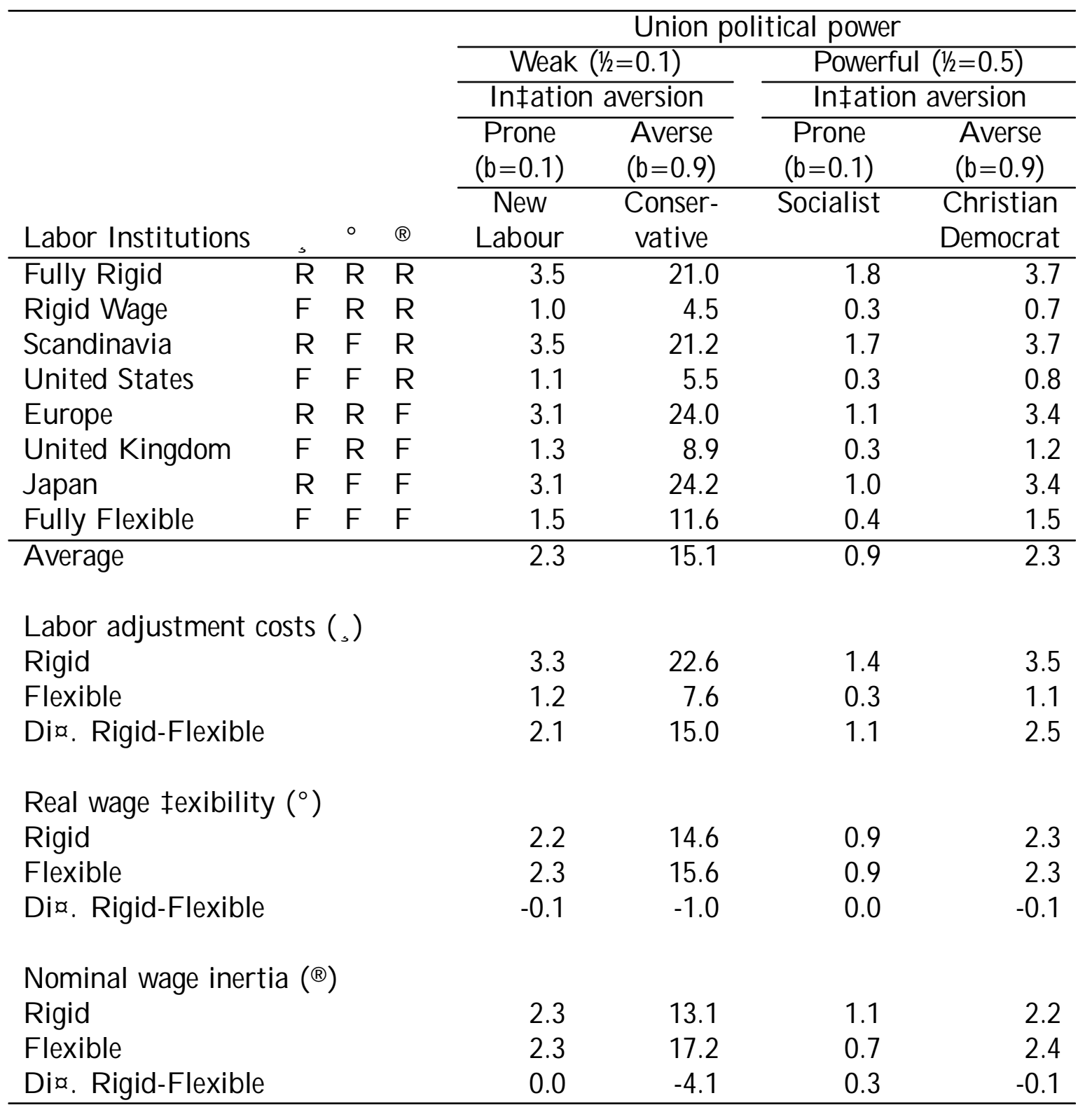

Notes. The cost of EMU measures the welfare cost, according to welfare function (5) in the text, of moving from the optimal parameters $x_{i}$ to the parameters $x_{i}=0$ for all i. All costs are normalized by the steady-state welfare corresponding to the speci..c political preference parameter con..guration and in percentage terms. The bottom panel reports the average cost for the 4 countries which share the indicated characteristic. Other parameters: ${ }^{-}=0: 9 ; r=0: 1 ; 3 / 4=3 / 4=0: 0004 ; q=0$. 
Table 5. Exect of labor market institutions on the cost of EMU.

\begin{tabular}{lccc}
\hline A. By policymaker's individual objectives: & \multicolumn{3}{c}{ Stabilize: } \\
\cline { 2 - 4 } Labor institution & Prices & Employment & Real wage \\
\hline Employment protection $($, $)$ & + & - & + \\
Real wage rigidity $\left(1=^{\circ}\right)$ & - & + & + \\
Nominal wage inertia $(\circledR)$ & - & + & + \\
\hline
\end{tabular}

B. By combinations of objectives:

\begin{tabular}{|c|c|c|c|c|}
\hline & \multicolumn{4}{|c|}{ Union political power } \\
\hline & \multirow{2}{*}{\multicolumn{2}{|c|}{$\begin{array}{c}\text { Weak }(1 / ₹ 0.1) \\
\text { Inłation aversion }\end{array}$}} & \multirow{2}{*}{\multicolumn{2}{|c|}{$\begin{array}{l}\text { Powerful (1/₹0.5) } \\
\text { In } \neq \text { ation aversion }\end{array}$}} \\
\hline & & & & \\
\hline & $\begin{array}{l}\text { Prone } \\
(b=0.1)\end{array}$ & $\begin{array}{l}\text { A verse } \\
(\mathrm{b}=0.9)\end{array}$ & $\begin{array}{l}\text { Prone } \\
(b=0.1)\end{array}$ & $\begin{array}{l}\text { A verse } \\
(b=0.9)\end{array}$ \\
\hline Labor institution & $\begin{array}{l}\text { New } \\
\text { Labour }\end{array}$ & $\begin{array}{l}\text { Conser- } \\
\text { vative }\end{array}$ & Socialist & $\begin{array}{l}\text { Christian } \\
\text { Democrat }\end{array}$ \\
\hline Employment protection (, ) & + & + & + & + \\
\hline Real wage rigidity $\left(1=^{0}\right)$ & - & - & + & - \\
\hline Nominal wage inertia ( $($ ) & + & - & + & - \\
\hline
\end{tabular}

Note: Panel A: A "+" (respectively "-") sign indicates that a more rigid institution increases (respectively reduces) the costs from EMU membership when the policymaker's objective is to stabilize the variable in the corresponding column. Source: Table A2. Panel B: Exect of each labor institution on the cost of EMU for each combination of policymaker's preferences. Source: Table 4.

Table 6. Exect of EMU on the incentives to reduce insiders' rents (q).

\begin{tabular}{lcrr}
\hline & $\begin{array}{c}\text { Cost of EMU } \\
\text { without reform } \\
\text { Country }\end{array}$ & $\begin{array}{c}\text { Cost of EMU } \\
\text { with reform } \\
(1)\end{array}$ & $\begin{array}{c}\text { Exect of EMU } \\
\text { on incentives (I) } \\
(1)-(2)\end{array}$ \\
\hline Fully Flexible & 7.9 & 10.9 & -3.0 \\
Europe & 15.9 & 16.3 & -0.4 \\
\hline
\end{tabular}

Note: Percentage costs of EMU, computed for a reform consisting of a reduction from $q=0$ to $q=i 0: 1$. For Fully Flexible,,$=1 ;{ }^{\circ}=4$, and ${ }^{\circledR}=0: 45$; for Europe, $=8 ;^{\circ}=1: 25$, and ${ }^{\circledR}=0: 45$. Other parameters: ${ }^{-}=0: 9 ; r=0: 1 ; 3 / 4=3 / 4.4=0: 0004$. 


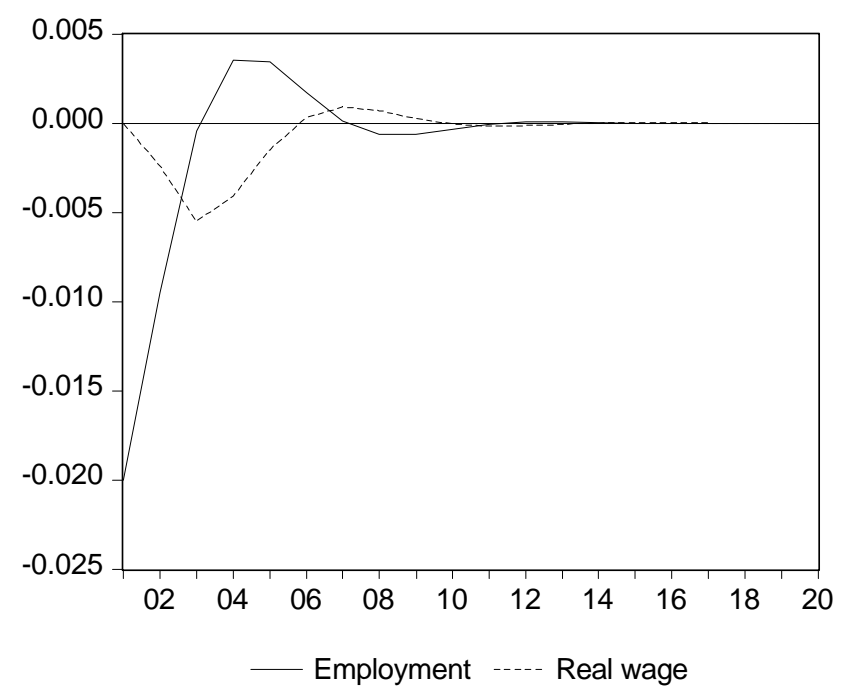

Figure 1: Dynamic response of employment and the real wage to a reduction in insider rents (q) in EMU. Fully Flexible economy.

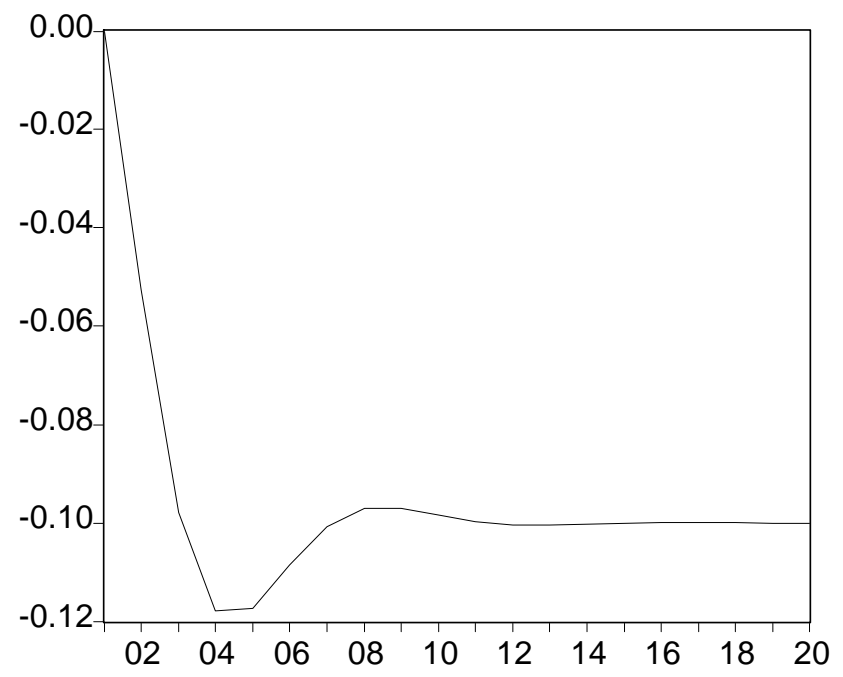

Figure 2: Dynamic response of the price level to a reduction in insider rents $(q)$ in EMU. Fully Flexible economy. 


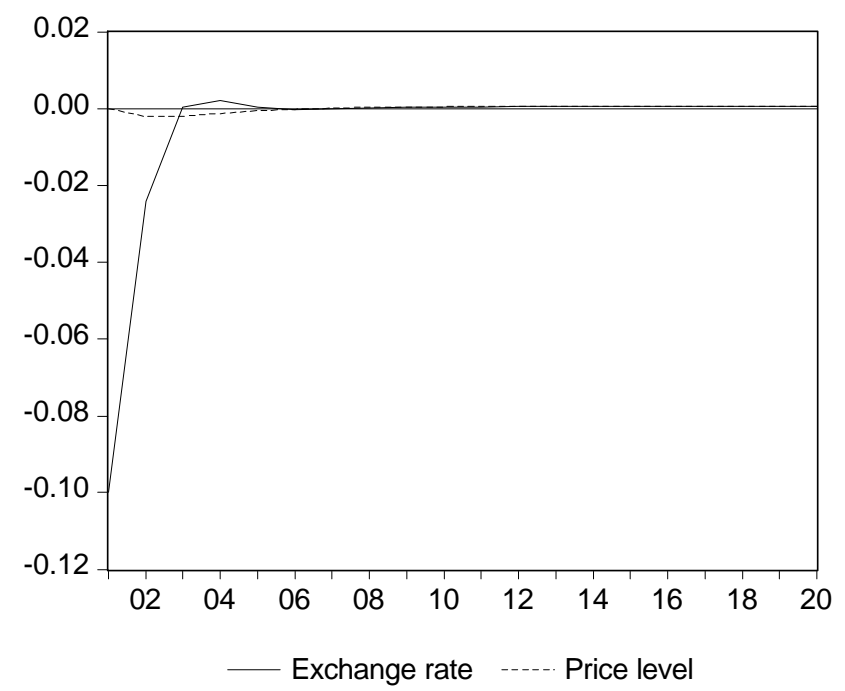

Figure 3: Dynamic response of the exchange rate and the price level to a reduction in insider rents (q) outside EMU. Fully F lexible economy.

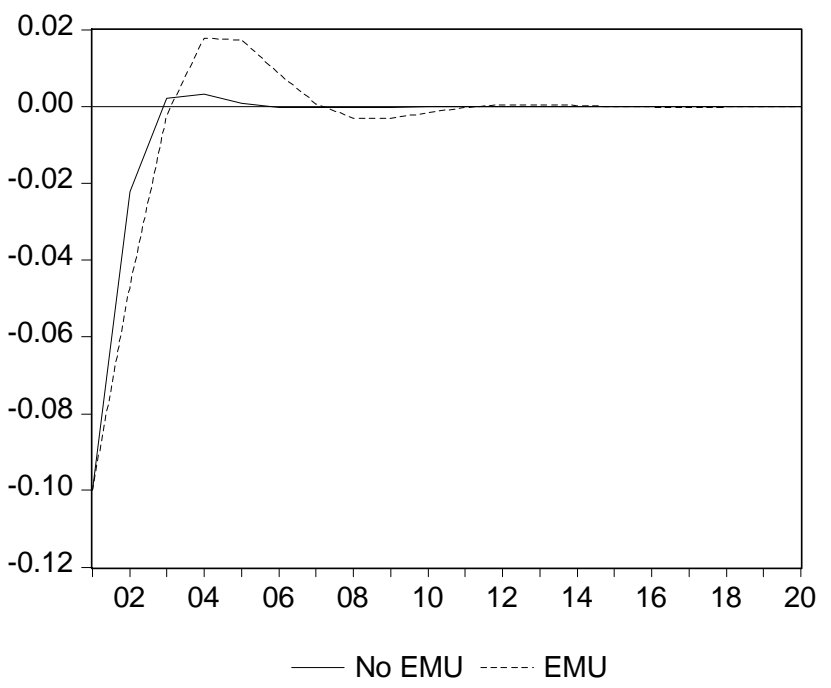

Figure 4: Dynamic response of the real exchange rate to a reduction in insider rents (q) in and outside EMU. Fully Flexible economy. 


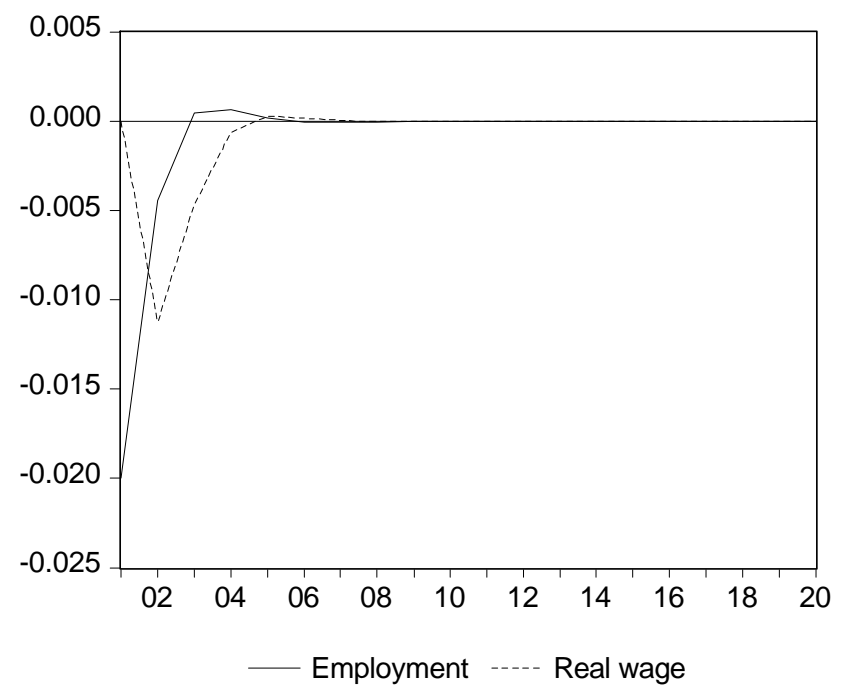

Figure 5: Dynamic response of employment and the real wage to a reduction in insider rents (q) outside EMU. Fully F lexible economy.

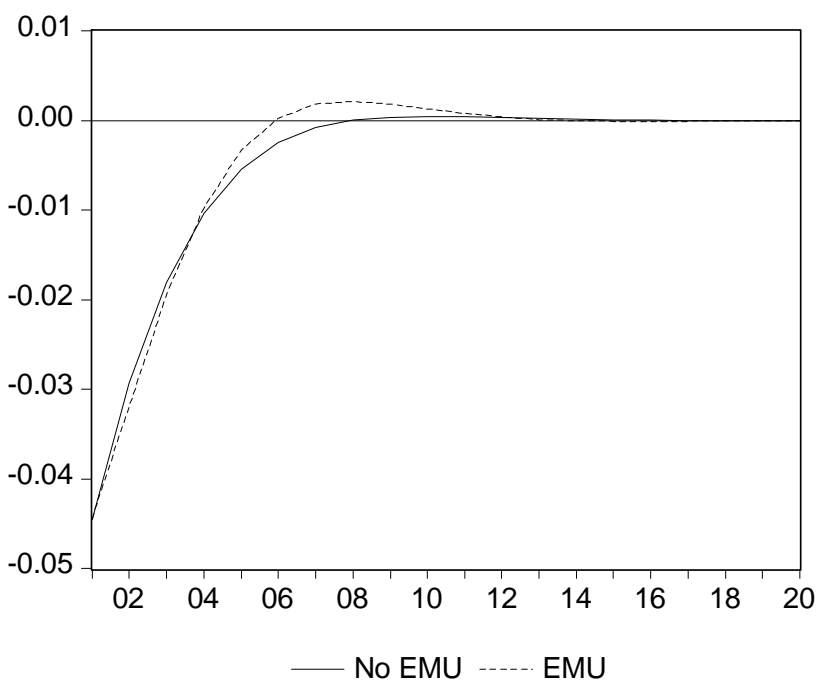

Figure 6: Dynamic response of employment to a reduction in insider rents $(q)$ in and outside EMU. "European" economy. 


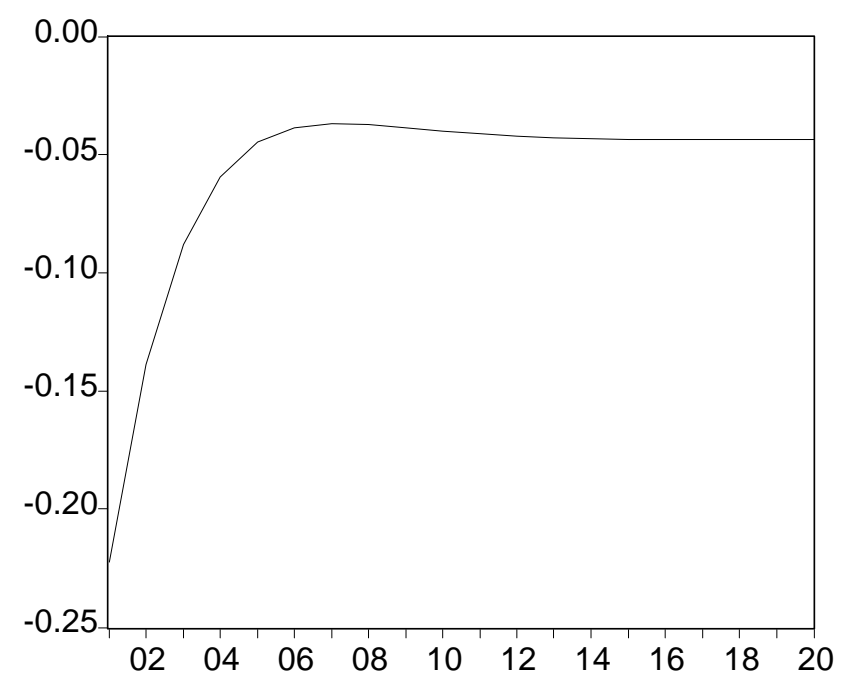

Figure 7: Dynamic response of the exchange rate to a reduction in insider rents (q) outside EMU. "European" economy.

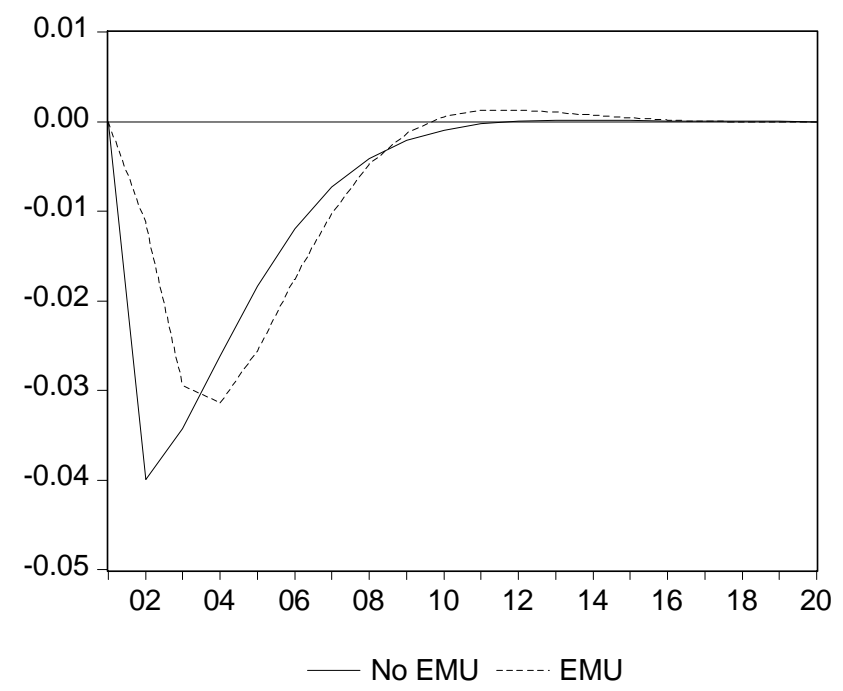

Figure 8: Dynamic response of the real wage to a reduction in insider rents $(q)$ in and outside EMU. "European" economy. 


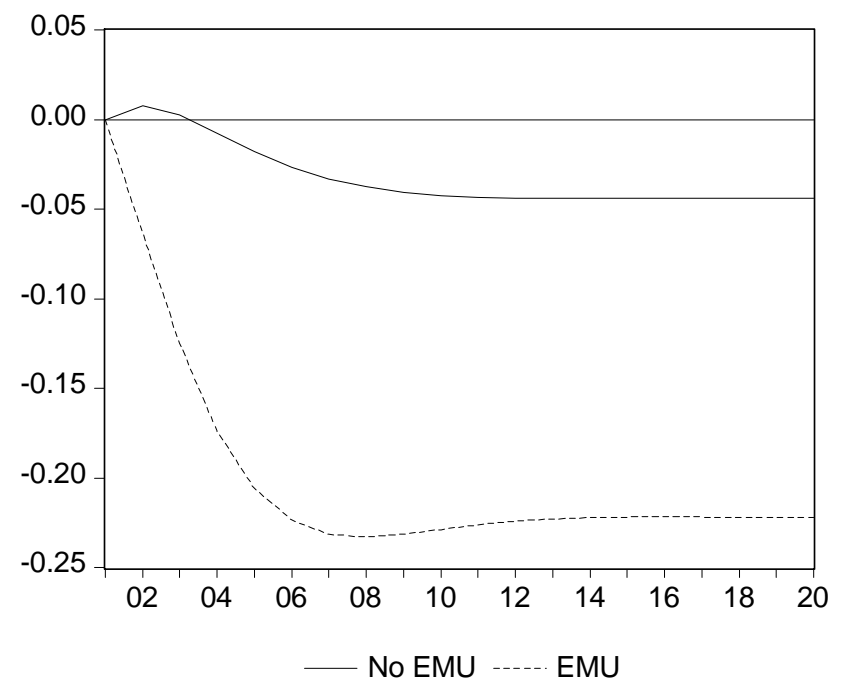

Figure 9: Dynamic response of the price level to a reduction in insider rents $(q)$ in and outside EMU. "European" economy. 